\title{
The influence of conjugated linoleic acid on the expression of peroxisome proliferator-activated receptor- $\gamma$ and selected apoptotic genes in non-small cell lung cancer
}

\author{
Bartosz Kazimierz Słowikowski ${ }^{1}$ D $\cdot$ Hanna Drzewiecka ${ }^{1} \cdot$ Michał Malesza $^{1} \cdot$ Ida Mądry $^{1} \cdot$ Karolina Sterzyńska $^{2}$. \\ Paweł Piotr Jagodziński ${ }^{1}$
}

Received: 25 March 2019 / Accepted: 21 January 2020 / Published online: 29 January 2020

(c) The Author(s) 2020

\begin{abstract}
In recent years, peroxisome proliferator-activated receptor- $\gamma$ (PPAR $\gamma$ ) has been intensively studied. Because its activation is often associated with changes in the expression level of various apoptotic genes, many studies have emphasized the role of PPAR $\gamma$ as an important anticancer agent. However, in different types of cancer, different genes are influenced by PPAR $\gamma$ action. Previous studies showed that conjugated linoleic acid (CLA) was able to induce apoptosis, upregulate PPARG gene expression and activate PPAR $\gamma$ protein in certain human cancer cell lines. Moreover, some PPAR $\gamma$ agonists inhibited the growth of human lung cancer cells through the induction of apoptosis. Nevertheless, the impact of CLA on PPAR $\gamma$ mRNA and protein levels in non-small cell lung cancer (NSCLC) cell lines has not been investigated thus far. Therefore, in our study, we analysed the influence of the c9,t11 linoleic acid isomer on the expression of PPARG and other genes involved in the apoptotic response (BCL-2, BAX, and CDKN1A) in two NSCLC cell lines of different histological origin (A549 and Calu-1) and in normal human bronchial epithelial Beas-2B cells. Cells were treated with several doses of c9,t11 CLA, followed by RNA and protein isolation, cDNA synthesis, real-time quantitative PCR (RT-qPCR) and Western blot analysis. We showed that the investigated CLA isomer was able to enhance the expression of PPAR $\gamma$ in the examined cell lines and alter the mRNA and protein levels of genes involved in apoptosis. Fluorescent staining and MMT assay revealed the antiproliferative potential of CLA as well as its ability to activate pathways that lead to cell death.
\end{abstract}

Keywords Ppar-gamma $\cdot$ Non-small cell lung cancer $\cdot$ CLA $\cdot$ Apoptosis

\section{Introduction}

According to recent statistics, lung cancer (LC) is the most commonly diagnosed type of tumour $(11.6 \%$ cases worldwide). However, its curability has not significantly improved, and it remains one of the most common causes of cancer

Bartosz Kazimierz Słowikowskia and Hanna Drzewiecka have contributed equally to this work.

Bartosz Kazimierz Słowikowski slowikowski.bartek@gmail.com

1 Department of Biochemistry and Molecular Biology, Poznan University of Medical Sciences, Święcickiego 6 Street, 60-781 Poznan, Poland

2 Department of Histology and Embryology, Poznan University of Medical Sciences, Święcickiego 6 Street, 60-781 Poznan, Poland death among men (22\%) and women (13.8\%) [1]. Approximately $85 \%$ of all diagnosed LC cases are non-small cell lung cancers (NSCLCs), which include several histopathological subtypes, mainly adenocarcinoma and squamous cell carcinoma [2].

The crucial risk factors for developing LC are mainly age and long-term exposure to tobacco smoke. Nevertheless, a significant increase in the incidence of non-smokers with LC has been observed in recent years. This phenomenon may be related to the continuously growing degree of air pollution [3]. For these reasons, and for a better understanding of the molecular development of LC, it seems sensible to seek new therapeutic and prophylactic factors that will contribute to the reduction of LC risk.

Conjugated linoleic acid (CLA) belongs to the family of essential fatty acids and naturally occurs as a mixture of many positional and geometric isomers, where cis-9,trans-11 (c9,t11) and cis-10,trans-12 (c10,t12) are 
the most biologically active structures $[4,5]$. The primary sources of CLA are the meat of ruminants and dairy products, in which approximately $90 \%$ of all CLAs occur as the c9,t11 isomer [4, 6]. CLA was discovered by Pariza et al. (1987) during a search for carcinogenic factors present in fried beef [6]. Eventually, CLA was found to possess anticarcinogenic and antiproliferative properties. Its pro-apoptotic action, as well as its inhibitory impact on cell growth, was revealed several times by using colon adenocarcinoma, gastric, prostate and breast cancer cell lines [7-10]. In addition, studies using animal models established that CLA exerts an inhibitory effect on chemically induced gastric, skin and breast cancer [7]. Research introduced by Sato et al. showed that the supplementation of CLA ( $2 \mathrm{~g} /$ day) can lead to its increase in serum to the concentration level $(36 \mu \mathrm{M} / \mathrm{l})$ that is considered to exhibit antiproliferative activity against human cancer cells [11].

It is commonly known that malignant tumours, including NSCLC, are characterized by dysregulation of many signalling pathways and insensitivity to pro-apoptotic signals, which leads to unlimited proliferation [10,12]. One of the mechanism responsible for the induction of apoptosis in cancer cells is the stimulation of peroxisome proliferatoractivated receptor- $\gamma$ (PPAR $\gamma$ ) by several factors, i.e. prostaglandins, glitazones and fatty acids (including CLA, which is its natural ligand) $[13,14]$. PPAR- $\gamma$ is encoded by PPARG gene and belongs to the family of nuclear receptors that act as transcription factors. PPAR- $\gamma$ regulates the expression of genes related to carbohydrate and lipid metabolism, immune system function, growth, differentiation and apoptosis [15]. PPAR- $\gamma$ exerts its effect through two different mechanisms. First, as a ligand-dependent transcription factor, PPAR- $\gamma$ can bind to DNA in the promoter region of genes with sequences known as peroxisome proliferator response elements (PPREs). Second, PPAR- $\gamma$ can control gene expression independently of PPREs by associating with activator proteins 1 and 2, which act as known transcription factors $[16,17]$.

Usually, activation of PPAR- $\gamma$ results in increased expression of genes that encode proteins responsible for the promotion of apoptosis (e.g. BAX, BAK, BAD, BID, and p21) and decreased expression of genes encoding anti-apoptotic agents (e.g. BCL-2) [16, 18]. This process results in enhanced programmed cell death, which limits the viability and proliferation of cancer cells [8-10, 17-19]. It was shown that stimulation of PPAR- $\gamma$ in cancers affects the expression of several genes associated with apoptosis, i.e. MYC in thyroid cancer, GADD153 (growth arrest and DNA damageinducible 153) in colon cancer and LC and POX (proline oxidase) in colon cancer. Furthermore, activation of PPAR- $\gamma$ inhibits the development of colon, lung, and breast cancer cells in vitro and exerts a suppressive impact on the progression of NSCLC in animal models [20, 21].
Intensive studies on CLA showed that its antiproliferative effect is a complex and multidirectional process. One of the antiproliferation mechanisms may be connected with the activation of PPAR- $\gamma$. In vitro research performed on hepatic cancer cell lines pinpointed CLA as an activation ligand of PPAR- $\gamma$ as well as an enhancer of PPARG expression, suggesting its impact on pro-apoptotic actions in cancer cells $[6,8,12,18]$.

In contrast, in other cells (e.g. neurons and cardiac cells), PPAR- $\gamma$ has protective effects. It was demonstrated that PPAR- $\gamma$ upregulated BCL-2 and induced the stability of mitochondria, thus providing protection against oxidative stress and associated apoptosis [22,23]. The mechanism of this specific phenomenon may be related to the concentration of the stimulating ligand-high levels of PPAR- $\gamma$ ligands may have pro-apoptotic properties, while at lower concentrations, they may exert anti-apoptotic actions [24]. This particular curiosity is called "a U-shaped dose-response relationship" or "hormesis" and is widely documented, especially in the field of pharmacology and toxicology. In regard to concentration, some substances may act positively or negatively [25].

Because LC remains the most common cancer diagnosed, there is a need to look for new possible protective factors. CLA, which is present in various types of food and very commonly used in dietary supplements, may be one such factor. The main aim of our study was to investigate the influence of the most common c9, t11 CLA isomer on the expression of $P P A R G$ and selected pro- and anti-apoptotic genes (BAX,CDKNIA, and $B C L-2)$ as well as its impact on LC cells proliferation and viability. Experiments were performed by using two different NSCLC cell lines (A549 and Calu-1) and normal human bronchial epithelial cells (Beas-2B).

\section{Material and methods}

\section{Cell culture}

Human A549 (adenocarcinoma) and Calu-1 (squamous cell carcinoma) NSCLC cells were purchased from American Type Culture Collection (Rockville, MD). Normal human bronchial epithelial Beas-2B cells were kindly provided by Dr M. Rusin from the Maria Skłodowska-Curie Memorial Cancer Center and Institute of Oncology, Gliwice Branch, Poland. A549 and Calu-1 cell lines were routinely maintained in RPMI 1640 medium (Sigma Aldrich, St. Louis, MO), while Beas-2B cells were cultured in DMEM/F12 medium (Sigma Aldrich, St. Louis, MO). Both media were supplemented with $10 \%$ heat-inactivated foetal bovine serum, $2 \mathrm{mM}$ glutamine, and $1 \%$ penicillin-streptomycin solution (10.000 units of penicillin and $10 \mathrm{mg}$ of 
streptomycin/ml; Sigma Aldrich, St. Louis, MO). Cells were grown at $37{ }^{\circ} \mathrm{C}$ in humidified air with $5 \% \mathrm{CO}_{2}$.

\section{Incubation with c9, t11 CLA}

Because we expected an intensified apoptotic effect, we carried out several minor experiments to establish appropriate doses of CLA and incubation times for each cell line (in order to avoid cytotoxicity and misleading results). Our assessment was based mainly on the measurement of cell number and viability in the subsequent days of incubation. This process was crucial for an efficient protein and RNA isolation, as well as for cDNA synthesis. For this purpose, we used Trypan blue staining (Thermo Fisher, Waltham, USA) and EVE ${ }^{\mathrm{TM}}$ Automated Cell Counter (NanoEnTek, Seoul, North Korea). In order to investigate the effect of c9, t11 CLA (Sigma Aldrich, St. Louis, MO) on PPARG, $B C L-2, B A X$, and $C D K N 1 A$ expression level we found the following conditions to be the most suitable:

A549 cells were cultured for 24,48 and $72 \mathrm{~h}$ in the presence of three different doses of c9, t11 CLA (50 $\mu \mathrm{M}$, $100 \mu \mathrm{M}$, and $200 \mu \mathrm{M}$ ).

Calu-1 cells were grown for 24 and $48 \mathrm{~h}$ using three concentrations of c9, t11 CLA $(25 \mu \mathrm{M}, 50 \mu \mathrm{M}$, and $75 \mu \mathrm{M})$.

Beas-2B cells were incubated for 24,48 and $72 \mathrm{~h}$ with c9, t11 CLA at concentrations of $25 \mu \mathrm{M}, 50 \mu \mathrm{M}$, and $75 \mu \mathrm{M}$.

The stock solutions of c9, t11 CLA were prepared in DMSO, aliquoted and stored at $-20{ }^{\circ} \mathrm{C}$ until later use. Before each experiment, c9, t11 CLA from the stock solution was diluted in cell culture media to the desired concentration and added to culture vessels. The stimulation media were exchanged every $24 \mathrm{~h}$. All experiments were performed in three biological repeats and included a control sample treated with appropriate amounts of DMSO (vehicle control), the concentration of which never exceeded $0.1 \%$, which is standard culturing practice.

\section{RNA isolation, reverse transcription, and Real-time quantitative PCR}

Total cellular RNA was isolated by TRIzol®) (Thermo Fisher, Waltham, USA) according to the manufacturer's protocol. The quantity and purity of the obtained material was evaluated spectrophotometrically by using a NanoDrop ${ }^{\mathrm{TM}}$ One (Thermo Fisher, Waltham, USA). To determine the integrity of isolated RNA, we performed agarose gel electrophoresis. Isolated samples were stored at $80^{\circ} \mathrm{C}$ until further analysis.

To obtain high-quality cDNA, we used SuperScript IV reverse transcriptase (Thermo Fisher Scientific, Waltham, USA) along with the mixture of oligo dT primers and hexamers (according to the manufacturer's protocol). Realtime quantitative PCR (RT-qPCR) was carried out in the
Light Cycler®480 Real-Time PCR System (Roche Diagnostics GmbH, Mannheim, Germany). PPARG, BCL-2, and $C D K N 1 A$ genes were analysed using LightCycler ${ }^{\circledR}$ 480 SYBR Green I Master (Roche Diagnostics GmbH, Mannheim, Germany). Because the $B A X$ sequence is very repetitive, to preserve specificity, we used a pre-designed PrimePCR ${ }^{\text {TM }}$ Probe Assay (Bio-Rad, Hercules, California, USA) to estimate the $B A X$ expression level.

The efficiency of all reactions was calculated by generating standard curves from a serial dilution of cDNA template mix from all of the samples. Every experiment included negative, no-template, non-transcribed RNA and genomic DNA controls. For calibration purposes, we used $1 \mu \mathrm{l}$ of cDNA template mix. The quantity of examined transcripts in each analysis was standardized with the geometric mean of three housekeeping genes-porphobilinogen deaminase $(P B G D)$; human mitochondrial ribosomal protein L19 (hMRPL19); and RNA polymerase II subunit A (POLR2A). The melting curve analysis and agarose gel electrophoresis were performed to confirm the specificity of the SYBR Green PCR products.

\section{Protein isolation, sodium dodecyl sulphate- polyacrylamide gel electrophoresis (SDS-PAGE) and Western blotting analysis}

For protein isolation, harvested cells were mixed with RIPA lysis buffer (Sigma Aldrich, St. Louis, USA) enriched with Roche cOmplete ${ }^{\mathrm{TM}}$ protease inhibitor cocktail (Sigma Aldrich, St. Louis, USA), incubated on ice for $30 \mathrm{~min}$ and centrifuged at $10,000 \times g$ for $10 \mathrm{~min}$ at $4{ }^{\circ} \mathrm{C}$ in order to remove cellular debris. Next, $30 \mu \mathrm{g}$ of total protein was resuspended in sample loading buffer, incubated in 99C for 12 min, cooled down on ice and separated on $12 \%$ Tris-Glycine gels, using sodium dodecyl sulphate-polyacrylamide gel electrophoresis (SDS-PAGE). Proteins from gels were electrotransfered to a nitrocellulose membrane, which was then blocked with 5\% non-fat dry milk in $1 \times$ concentrated Tris- $\mathrm{HCl}$ saline/Tween buffer. After blocking, membranes were incubated in $4^{\circ} \mathrm{C}$ with anti-PPAR- $\gamma$ or anti-BCL-2 monoclonal antibody (Santa-Cruz, California, USA) at the dilution of 1:500. This process was followed by washing membranes in $1 \times$ Tris-HCL saline/Tween buffer and placing them in the solution of secondary antibody conjugated with horseradish peroxidase (1:1000); (Santa-Cruz, California, USA). Immunochemiluminescent signal was revealed using SuperSignal West Femto Chemiluminescent Substrate (Thermo Fisher, Waltham, USA) and ChemiDoc MP imaging system (Bio-Rad, Hercules, California, USA). Next, membranes were restriped and incubated with anti-GAPDH anibody (FL-335) (1:5000) (Santa-Cruz, California, USA) followed by incubation with secondary goat anti-rabbit HRP-conjugated antibody (1:5000). The amount of analysed 
proteins was demonstrated as the investigated protein-toGAPDH optical density ratio. Optical density was measured by using ImageJ $2 x$ programme [26].

\section{MTT cell proliferation assay}

To determine the cytotoxic and antiproliferative effect of $c 9$, t11 CLA on examined cell lines we used MTT proliferation assay (Sigma Aldrich, St. Louis, USA). Cells were cultured in DMEM/F12 (Beas-2B) or RPMI 1640 (A549, Calu-1) medium enriched with $10 \%$ FBS for $24 \mathrm{~h}$ and then seeded into 96-well plates at the density of $3.5 \times 10^{3}$ (A549 and Beas-2B) and $7.0 \times 10^{3}$ (Calu-1) cells per well. Next, cells were incubated in the presence of different doses of CLA $(25 \mu \mathrm{M}, 50 \mu \mathrm{M}, 75 \mu \mathrm{M}$ for Beas-2B and Calu-1; $50 \mu \mathrm{M}$, $100 \mu \mathrm{M}, 200 \mu \mathrm{M}$ for A549) for 24,48 and $72 \mathrm{~h}$. After the incubation period, all media were removed and replaced by $200 \mu \mathrm{l}$ of $10 \%$ MTT solution (5 mg of MTT substrate per $1 \mathrm{ml}$ of PBS) in FBS-free cell culture medium and left for $4 \mathrm{~h}$ in the incubator. After this time MTT mixture was carefully discarded and newly formatted formazan crystals were dissolved by adding $50 \mu \mathrm{l}$ of DMSO into each well. The absorbance was measured by Epoch Plate Spectrophotometer (BioTek, Vinooski,VT, USA). Each experiment was performed in 8 biological repeats for each CLA concentration and included 8 vehicle controls (with DMSO).

\section{Fluorescence microscopy}

To evaluate the impact of $c 9, t 11$ CLA on cell cell membrane integrity we performed bis-benzimide (Hoechst 33,342; Sigma Aldrich, St. Louis, USA) and propidium iodide (PI); (Sigma Aldrich, St. Louis, USA) double fluorescent staining. Hoechst 33,342 (blue) has an ability to penetrate the intact cell membranes while the PI (red), due to its electrical charge is a membrane impermeant dye. However, PI stains cells with damaged membranes, which are characteristic for late-apoptotic and dead cells. Before staining, cells were incubated in the presence or absence (vehicle controls) of different doses of CLA (as described above) for $72 \mathrm{~h}$ in chamber slides (Thermo Fisher, Waltham, USA). After the experiment, cells were washed twice with $1 \times$ PBSand incubated with Hoechst 33,342 solution $(1 \mu \mathrm{g} / \mathrm{ml})$ for $10 \mathrm{~min}$ in the dark at room temperature. Next, cells were washed again $(3 \times$ with $1 \times$ PBS $)$, and incubated with PI solution $(1 \mu \mathrm{g} / \mathrm{ml})$ for 5 min and rinsed 3 times with PBS before visualization. The fluorescent signal was detected by Zeiss Axio-Imager Z1 (Carl Zeiss, Microscopy GmbH, Oberkochen, Germany).

\section{Statistical analysis}

The normality of the observed data distribution was established by the Shapiro-Wilk test. The one-way analysis of variance (ANOVA) with post-hoc HSD Tukey-Kramer test were used to compare the mean values of $P P A R G, B C L-2$, $B A X$, and $C D K N 1 A$ transcript levels and to identify statistically significant differences between the control samples and the c9,t11 CLA-treated cells. The ANOVA with post-hoc HSD Tukey-Kramer test was used to compare mean values of the absorbancy level of MTT assay. Gene expression as well as protein level is displayed as the multiplicity of the respective controls at selected incubation times. To determine whether there are any significant associations between the expression levels of investigated genes, we performed a Pearson correlation analysis (the distribution of the data was normal). A $p$ value $<0.05$ was considered statistically significant. All statistical analyses were performed by using GraphPad in Stat 3.10 and STATISTICA 13 software.

\section{Results}

\section{Evaluation of the $c 9, t 11$ CLA effect on the mRNA and protein levels of the investigated genes in A549 cell line}

Data concerning the relative expression levels of the investigated genes and Western blot results for A549 cells are presented in Fig. 1 and Table 1. Our analysis revealed that $P P A R G$ transcript levels significantly increased after $24 \mathrm{~h}$ $(p=0.0006)$ and $48 \mathrm{~h}(p=0.0125)$ of $\mathrm{c} 9, \mathrm{t} 11 C L A$ stimulation (Fig. 1a). However, after $72 \mathrm{~h}$ of incubation with CLA at a dose of $200 \mu \mathrm{M}$, we noticed a drop in the PPARG expression level $(p=0.0077)$. Statistically significant difference in $P P A R G$ mRNA levels at $72 \mathrm{~h}$ occurred between untreated vehicle controls and the highest concentration of investigated compound ( $p<0.01)$. According to the chart (Fig. 1a), we observed the following pattern: the higher the concentration of stimulant was, the greater the increase after 24 and $48 \mathrm{~h}$ and the greater the decrease in expression of $P P A R G$ after $72 \mathrm{~h}$. The increase in transcript levels of $P P A R G$ was confirmed by changes in protein amounts (Fig. 1b). A similar trend was noticed in t case of $\mathrm{t} B C L-2$ gene (Fig. 1a). CLAtreated cells demonstrated meaningful upregulation of $B C L$ 2 expression after $24 \mathrm{~h}(p=0.001)$ and $48 \mathrm{~h}(p=0.0019)$ which returned to the basal level after $72 \mathrm{~h}$. The protein level of BCL-2 has also increased, although this effect was mostly observed after $72 \mathrm{~h}$ of the CLA treatment (Fig. 1b). The other investigated genes revealed only subtle changes in the expression level. The $B A X$ transcripts level decreased after $72 \mathrm{~h}$ of $\mathrm{c} 9, \mathrm{t} 11 \mathrm{CLA}$ treatment at highest concentrationdoses-(100 and $200 \mu \mathrm{M}) ;(p=0.0001)$; (Fig. 1b). The same trend was visible for $C D K N 1 A$, but the data did not reach statistical significance $(p=0.0596)$; (Fig. 1a). Moreover, Pearson correlation analysis revealed a strong correlation 
A
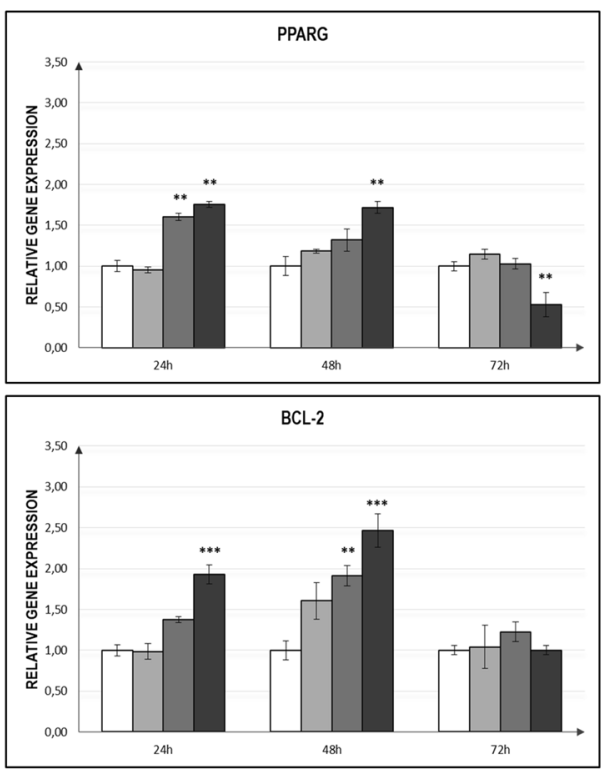

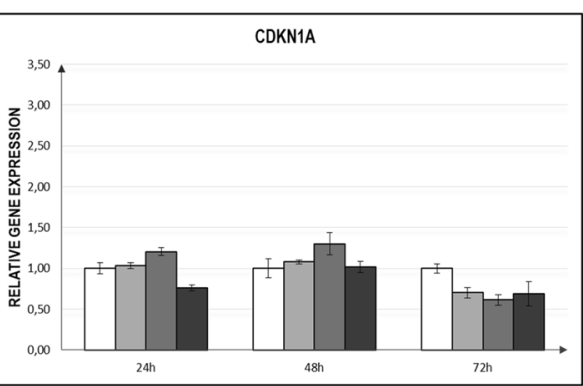

BAX

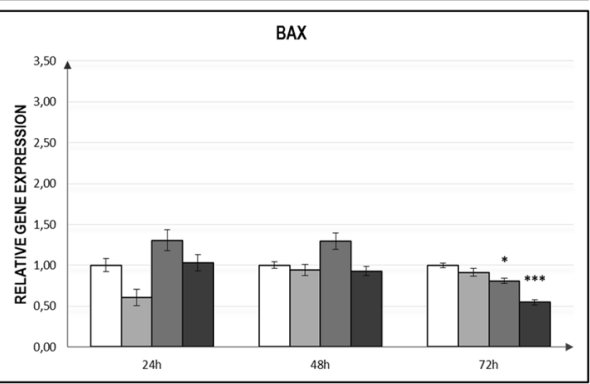

A549

Control

$50 \mu \mathrm{M}$ CLA

$100 \mu \mathrm{M}$ CLA

$200 \mu \mathrm{M} C L A$

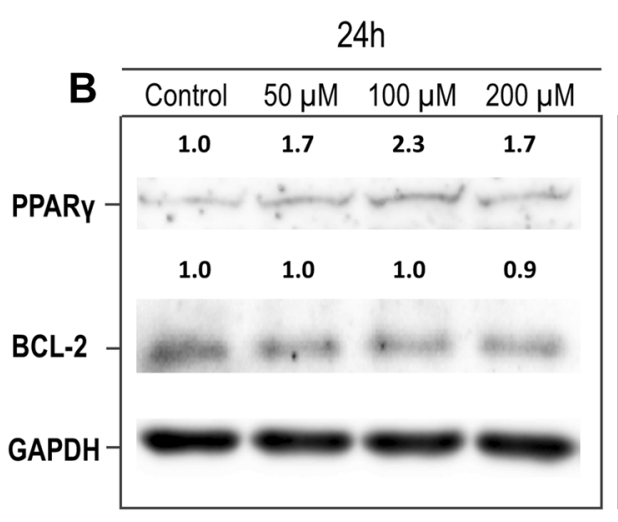

B

$48 \mathrm{~h}$

$72 \mathrm{~h}$
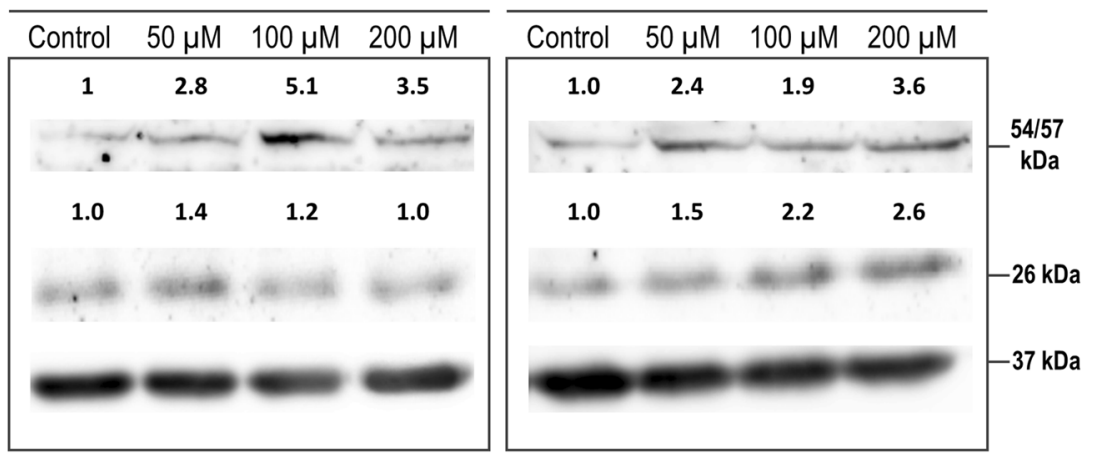

Fig. 1 a Relative expression levels of PPARG, CDKNIA, BCL-2 and $B A X$ genes in A549 cell line, after treatment with different doses of c9, t11 CLA in selected incubation times. Cells were maintained for $24 \mathrm{~h}$ to $72 \mathrm{~h}$ in the absence (controls, only DMSO) or in the presence of c9, t11 CLA at concentrations of 50, 100 and $200 \mu \mathrm{M}$. After incubation, cells were used for total RNA isolation and RT-qPCR analysis. Each gene transcript level is displayed as the mean multiplicity of the respective control samples \pm SEM. Statistically significant differences between control and tested cells are marked with asterisks ( ${ }^{*} p$ value $<0.05$; ${ }^{* *} p$ value $<0.01$; and ${ }^{* * *} p$ value $\left.<0.001\right)$. b Rep-

between PPARG and BCL-2 expression levels in A549 cells $\left(p=0.0001 ; r=0.5922 ; r^{2}=0.3507\right)$.

\section{Evaluation of the $c 9, \mathrm{t} 11$ CLA effect on the mRNA and protein levels of the investigated genes in Calu-1 cell line}

Data demonstrating changes in the relative expression levels of the investigated genes in Calu- 1 cells are presented in Fig. 2 and Table 2. Our analysis showed that the changes in the transcript levels of the examined genes in the Calu-1 cell line were not as striking as in A549 cells, although we resentative image of Western Blot analysis of PPAR- $\gamma$ and BCL-2 status in the A549 cell line. Cells were maintained for $24 \mathrm{~h}$ to $72 \mathrm{~h}$ in the absence (controls, only DMSO) or in the presence of c9, t11 CLA at concentrations of 50, 100 and $200 \mu \mathrm{M}$. Proteins were isolated by using RIPA buffer, separated by $10 \%$ SDS-PAGE and detected by Western Blotting. The numbers above the images of protein bands are optical density ratio values of PPAR- $\gamma$ or BCL-2 to GAPDH for each sample. The ratio of PPAR- $\gamma$ or BCL-2 to GAPDH for control cells in each incubation time was assumed to be 1 . The protein level was displayed as the mean multiplicity of the respective control sample

noticed some significant alterations. PPARG and $B C L$ 2 mRNA levels were elevated after $24 \mathrm{~h}(p=0.0019$ and $p=0.0031$, respectively) and $48 \mathrm{~h}(p=0.01$ and $p=0.0010$, respectively), especially in the presence of the highest dose of c9,t11 CLA (75 $\mu \mathrm{M})$; (Fig. 2a). Although the differences in transcript levels were not so prominent, the effect of CLA was more visible in case of proteins content. We observed elevated amounts of PPAR- $\gamma$ in the CLA-treated cells, especially at higher doses of the compound (Fig. 2b). Our Western blot analysis also demonstrated an increased BCL-2 protein values after $48 \mathrm{~h}$ of incubation period. Moreover, we showed that a statistically significant correlation occurred 
Table 1 Statistical analysis of PPARG, BCL-2, BAX and CDKN1A expression level in control and c9, t11 CLA-treated A549 cells in different times of incubation; $p$ value $<0.05$ was considered statistically significant

\begin{tabular}{|c|c|c|c|c|c|c|}
\hline \multirow[t]{3}{*}{ Cell line/gene } & \multirow{3}{*}{$\begin{array}{l}\text { Time of } \\
\text { incubation }\end{array}$} & \multicolumn{5}{|l|}{ A549 } \\
\hline & & \multicolumn{5}{|c|}{ Relative normalized expression } \\
\hline & & Control $( \pm$ SEM $)$ & $50 \mathrm{uM}( \pm \mathrm{SEM})$ & $100 \mathrm{uM}( \pm$ SEM $)$ & $200 \mathrm{uM}( \pm$ SEM $)$ & ANOVA $p$ value \\
\hline \multirow[t]{6}{*}{ PPARG } & \multirow[t]{2}{*}{$24 \mathrm{~h}$} & 1.00 & 0.95 & $1.60^{* *}$ & $1.76^{* *}$ & 0.0006 \\
\hline & & $( \pm 0.05)$ & $( \pm 0.02)$ & $( \pm 0.12)$ & $( \pm 0.14)$ & \\
\hline & \multirow[t]{2}{*}{$48 \mathrm{~h}$} & 1.00 & 1.18 & 1.32 & $1.72^{* *}$ & 0.0125 \\
\hline & & $( \pm 0.03)$ & $( \pm 0.08)$ & $( \pm 0.10)$ & $( \pm 0.19)$ & \\
\hline & \multirow[t]{2}{*}{$72 \mathrm{~h}$} & 1.00 & 1.15 & 1.03 & $\mathbf{0 . 5 3}^{* *}$ & 0.0077 \\
\hline & & $( \pm 0.04)$ & $( \pm 0.05)$ & $( \pm 0.14)$ & $( \pm 0.11)$ & \\
\hline \multirow[t]{6}{*}{$B C L-2$} & \multirow[t]{2}{*}{$24 \mathrm{~h}$} & 1.00 & 0.99 & 1.37 & $1.93 * * *$ & 0.0001 \\
\hline & & $( \pm 0.07)$ & $( \pm 0.10)$ & $( \pm 0.04)$ & $( \pm 0.11)$ & \\
\hline & \multirow[t]{2}{*}{$48 \mathrm{~h}$} & 1.00 & 1.61 & $1.91^{*}$ & $2.47^{* *}$ & 0.0019 \\
\hline & & $( \pm 0.11)$ & $( \pm 0.22)$ & $( \pm 0.12)$ & $( \pm 0.20)$ & \\
\hline & \multirow[t]{2}{*}{$72 \mathrm{~h}$} & 1.00 & 1.04 & 1.23 & 1.00 & $>0.05$ \\
\hline & & $( \pm 0.05)$ & $( \pm 0.26)$ & $( \pm 0.12)$ & $( \pm 0.15)$ & \\
\hline \multirow[t]{6}{*}{$B A X$} & \multirow[t]{2}{*}{$24 \mathrm{~h}$} & 1.00 & 0.76 & 1.30 & 1.03 & $>0.05$ \\
\hline & & $( \pm 0.04)$ & $( \pm 0.10)$ & $( \pm 0.13)$ & $( \pm 0.10)$ & \\
\hline & \multirow[t]{2}{*}{$48 \mathrm{~h}$} & 1.00 & 0.94 & 1.29 & 0.93 & $>0.05$ \\
\hline & & $( \pm 0.04)$ & $( \pm 0.07)$ & $( \pm 0.10)$ & $( \pm 0.06)$ & \\
\hline & \multirow[t]{2}{*}{$72 \mathrm{~h}$} & 1.00 & 0.91 & $0.81^{*}$ & $0.55^{* * *}$ & 0.0001 \\
\hline & & $( \pm 0.03)$ & $( \pm 0.05)$ & $( \pm 0.03)$ & $( \pm 0.03)$ & \\
\hline \multirow[t]{6}{*}{$C D K N 1 A$} & \multirow[t]{2}{*}{$24 \mathrm{~h}$} & 1.00 & 1.03 & 1.11 & 0.98 & $>0.05$ \\
\hline & & $( \pm 0.04$ & $( \pm 0.03)$ & $( \pm 0.05)$ & $( \pm 0.04)$ & \\
\hline & \multirow[t]{2}{*}{$48 \mathrm{~h}$} & 1.00 & 1.08 & 1.30 & 1.02 & $>0.05$ \\
\hline & & $( \pm 0.02)$ & $( \pm 0.02)$ & $( \pm 0.14)$ & $( \pm 0.07)$ & \\
\hline & \multirow[t]{2}{*}{$72 \mathrm{~h}$} & 1.00 & 0.70 & 0.61 & 0.69 & $>0.05$ \\
\hline & & $( \pm 0.05)$ & $( \pm 0.06)$ & $( \pm 0.06)$ & $( \pm 0.15)$ & \\
\hline
\end{tabular}

Asterisk marked results significantly differs compared to untreated control—samples measurements $(* p$ value $<0.05 ; * * p$ value $<0.01 ; * * * p$ value $<0.001$ )

between PPARG and BCL-2 transcript levels ( $p=0.04$, $r=0.37, r^{2}=0.13$ ). However, the correlation was much weaker compared to the correlation between these two genes in the A549 cell line. Next, a small but significant upregulation of CDKNIA expression was observed when CLA was used at the dose of $75 \mu \mathrm{M}$, regardless of time (for $24 \mathrm{~h}$ $p=0.001$ and for $48 \mathrm{~h} p=0.0221$ ); (Fig. 2a). $p=p=$ Similar to the results in A549 cells, our study also revealed a substantial drop in $B A X$ expression level after $48 \mathrm{~h}$ of incubation with the highest applied dose of CLA (Fig. 2a).

\section{Evaluation of the $c 9, \mathrm{t} 11$ CLA effect on the mRNA and protein levels of the investigated genes in Beas-2B cell line}

All results concerning the impact of the c9,t11 CLA isomer on the expression level of analysed genes are shown in Fig. 3 and Table 3. During the analysis of Beas-2B samples, we observed the most noticeable and substantial increase of PPARG transcript levels in stimulated cells compared to the other stimulated NSCLC cell lines (Fig. 3a). PPARG overexpression was noticed after $48 \mathrm{~h}$ $(p=0.0016)$ and $72 \mathrm{~h}(p=0.0015)$ of incubation, regardless of the concentration of the stimulant. This effect was confirmed by the protein analysis, however the most visible changes were revealed after $72 \mathrm{~h}$ of treatment (Fig. 3b). Furthermore, the application of c9,t11 CLA at a dose of $75 \mu \mathrm{M}$ resulted in an increase in the quantity of $B A X$ mRNA level after $48 \mathrm{~h}(p=0.0016)$ and $72 \mathrm{~h}(p=0.0103)$ of treatment (Fig. 3a). Interestingly, in the contrary to previous results from NSCLC cell lines, we found a strong positive correlation between PPARG and BAX transcript levels $\left(p=0.0001 ; r=0.6399 ; r^{2}=0.4094\right)$ in Beas-2B cells. The other investigated genes did not reveal major changes. Although we also observed a certain trend towards elevated $B C L-2$ expression, this outcome did not reach statistical significance (Fig. 3a). Lastly, the level of CDKN1A was not affected by c9,t11 CLA (Fig. 3a). 
A
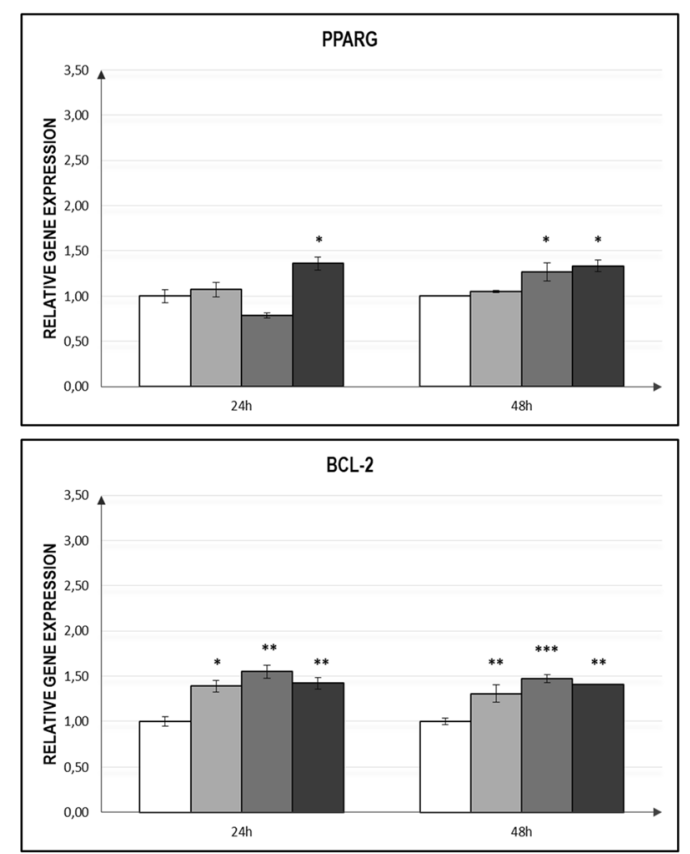

B

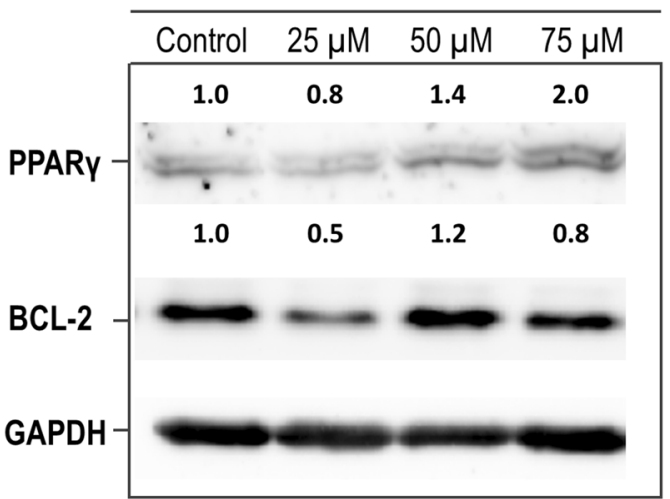

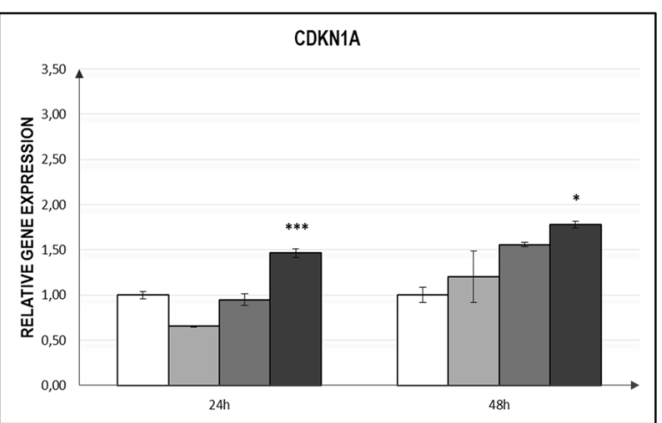

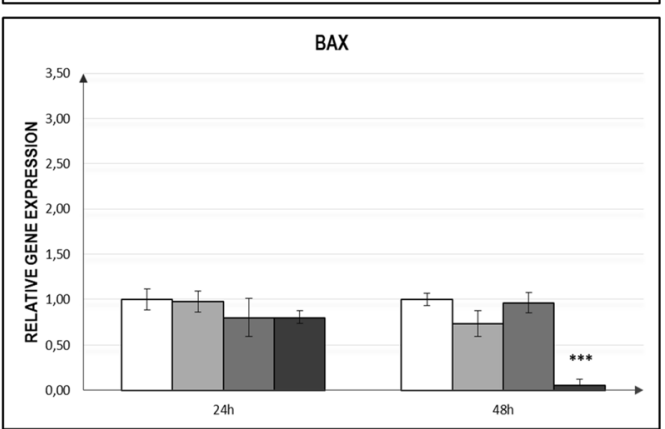

$48 \mathrm{~h}$
Calu-1

Control

$25 \mu \mathrm{M}$ CLA

$50 \mu \mathrm{M}$ CLA

$75 \mu \mathrm{M}$ CLA
Fig. 2 a Relative expression levels of PPARG, CDKN1A, BCL-2 and $B A X$ genes in the Calu-1 cell line, after treatment with different doses of $\mathrm{c} 9, \mathrm{t} 11$ CLA in selected incubation times. Cells were maintained for $24 \mathrm{~h}$ to $48 \mathrm{~h}$ in the absence (controls) or in the presence of $\mathrm{c} 9, \mathrm{t} 11$ CLA at concentrations of 25,50 and $75 \mu \mathrm{M}$. After incubation, cells were used for total RNA isolation and RT-qPCR analysis. Each gene transcript level is displayed as the mean multiplicity of the respective control samples \pm SEM. Statistically significant differences between control and tested samples are marked with asterisks $\left({ }^{*} p\right.$ value $<0.05$; $* * p$ value $<0.01$; and $* * * p$ value $<0.001)$. b Representative image

\section{Evaluation of the $\mathrm{c} 9, \mathrm{t} 11 \mathrm{CLA}$ impact on cell viability, proliferation and membrane integrity}

All results concerning the influence of $\mathrm{c} 9$, t11 CLA isomer on cell viability, proliferation and morphology are shown in Figs. 4, 5, 6, 7, 8. In order to examine the effect of c9, t11 CLA on A549, Calu-1 and Beas-2B cell viability and proliferation, we used the MTT assay. As described above, we treated cells with different doses of CLA, over a period of Western Blot analysis of PPAR- $\gamma$ and BCL-2 status in Calu- 1 cell line. Cells were maintained for $24 \mathrm{~h}$ to $72 \mathrm{~h}$ in the absence (controls, only DMSO) or in the presence of $\mathrm{c} 9, \mathrm{t} 11$ CLA at concentrations of 25,50 and $75 \mu \mathrm{M}$. Proteins were isolated by using RIPA buffer, separated by $10 \%$ SDS-PAGE and detected by Western Blotting. The numbers above the images of protein bands are optical density ratio values of PPAR- $\gamma$ or BCL-2 to GAPDH for each sample. The ratio of PPAR- $\gamma$ or BCL-2 to GAPDH for control cells in each incubation time was assumed to be 1 . The protein level was displayed as the mean multiplicity of the respective control sample of 24, 48 and $72 \mathrm{~h}$. We observed that CLA significantly decreased cell proliferation of every tested cell line, regardless of its concentration (Fig. 4a-c). The strongest effect was noticed after $72 \mathrm{~h}$ of incubation, at the highest applied doses. In addition to MTT assay we decided to stain all cells with Hoechst 33,342 and PI dyes in order to determine cell membrane integrity. While Hoechst 33,342 (blue) uptake is observed in every cell, irrespective of cell viability, the PI (red) is meant to stain cells with disturbed membrane 
Table 2 Statistical analysis of $P P A R G, B C L-2, B A X$ and $C D K N 1 A$ expression level in control and c9,t11 CLA-treated Calu-1 cells in different times of incubation; $p$ value $<0.05$ was considered statistically significant

\begin{tabular}{|c|c|c|c|c|c|c|}
\hline \multirow[t]{3}{*}{ Cell line/gene } & \multirow{3}{*}{$\begin{array}{l}\text { Time of incu- } \\
\text { bation }\end{array}$} & \multicolumn{5}{|l|}{ Calu-1 } \\
\hline & & \multicolumn{5}{|c|}{ Relative normalized expression } \\
\hline & & Control $( \pm$ SEM $)$ & $25 \mathrm{uM}( \pm$ SEM $)$ & $50 \mathrm{uM}( \pm \mathrm{SEM})$ & $75 \mathrm{uM}( \pm$ SEM $)$ & ANOVA $p$ value \\
\hline \multirow[t]{4}{*}{ PPARG } & $24 \mathrm{~h}$ & 1.00 & 1.07 & 0.84 & $1.36^{*}$ & 0.0019 \\
\hline & & $( \pm 0.07)$ & $( \pm 0.08)$ & $( \pm 0.03)$ & $( \pm 0.07)$ & \\
\hline & $48 \mathrm{~h}$ & 1.00 & 1.05 & $1.27^{*}$ & $1.33^{*}$ & 0.01 \\
\hline & & $( \pm 0.01)$ & $( \pm 0.01)$ & $( \pm 0.10)$ & $( \pm 0.06)$ & \\
\hline \multirow[t]{4}{*}{$B C L-2$} & $24 \mathrm{~h}$ & 1.00 & $1.31^{*}$ & $1.47^{* *}$ & $1.42^{* *}$ & 0.0031 \\
\hline & & $( \pm 0.05)$ & $( \pm 0.07)$ & $( \pm 0.07)$ & $( \pm 0.06)$ & \\
\hline & $48 \mathrm{~h}$ & 1.00 & $1.39^{* * *}$ & $1.55^{* * *}$ & $1.41^{* *}$ & 0.0010 \\
\hline & & $( \pm 0.04)$ & $( \pm 0.10)$ & $( \pm 0.05)$ & $( \pm 0.00)$ & \\
\hline \multirow[t]{4}{*}{$B A X$} & $24 \mathrm{~h}$ & 1.00 & 0.97 & 0.80 & 0.80 & $>0.5$ \\
\hline & & $( \pm 0.12)$ & $( \pm 0.12)$ & $( \pm 0.21)$ & $( \pm 0.15)$ & \\
\hline & $48 \mathrm{~h}$ & 1.00 & 0.74 & 0.96 & $0.06{ }^{* * *}$ & 0.00040 \\
\hline & & $( \pm 0.07)$ & $( \pm 0.14)$ & $( \pm 0.11)$ & $( \pm 0.00)$ & \\
\hline \multirow[t]{4}{*}{$C D K N 1 A$} & $24 \mathrm{~h}$ & 1.00 & 0.84 & 0.95 & $1.46^{* * *}$ & 0.001 \\
\hline & & $( \pm 0.04)$ & $( \pm 0.01)$ & $( \pm 0.07)$ & $( \pm 0.05)$ & \\
\hline & $48 \mathrm{~h}$ & 1.00 & 1.20 & 1.56 & $1.78^{*}$ & 0.0221 \\
\hline & & $( \pm 0.08)$ & $( \pm 0.28)$ & $( \pm 0.03)$ & $( \pm 0.03)$ & \\
\hline
\end{tabular}

Asterisk marked results significantly differs compared to untreated control—samples measurements $(* p$ value $<0.05 ; * * p$ value $<0.01 ; * * * p$ value $<0.001)$

permeability, which is known characteristic feature of lateapoptotic or necrotic cells. As presented on Figs. 5, 6, 7, the strongest fluorescence signal of PI was observed in cells treated with the highest doses of the CLA $(150 ; 200 \mu \mathrm{M})$. In addition, the CLA-related effect can also be observed in the standard microscopic images, where the number of cells and changes in cell morphology are visible (Fig. 8). The number of cells present in culture vessels decreased with increasing doses of CLA. Moreover, those cells exposed to CLA showed some apoptosis-related morphological changes like nuclei fragmentation (Fig. 6d, e) or presence of small intracellular bodies (Fig. 8d-f) compared to respective controls.

\section{Discussion}

LC development is directly connected to an unhealthy lifestyle. It is commonly known that many people with this disease are current or former smokers [2, 27]. Nevertheless, the growing incidence of LC in never smokers [28], caused mainly by growing air pollution [3], or second-hand smoking forces science to seek additional preventive and prophylactic factors. It is well known that cancer cells are characterized by an impaired balance between death and proliferation. A deep understanding of this disparity should improve and speed up the discovery of improved preventive agents. CLA seems to be one such factor. This fatty acid naturally occurs as a mixture of isomers, where the $\mathrm{c} 9, \mathrm{t} 11$ isomer is the most abundant. CLA is predominantly present in ruminant meat and dairy products and is currently a popular compound in various dietary supplements $[4,6]$. CLA was first discovered in 1987 by Pariza et al. [6]. Since then, numerous studies have been carried out, pinpointing the anticancer potential of CLA [29], especially in colon, stomach, prostate and hepatic cancer [8-10, 30, 31]. One of the target proteins through which CLA can interact is PPAR- $\gamma$ [13], the activation of which is related to pro-apoptotic and antiproliferative features [19, 21].

Even though much is known about PPAR- $\gamma$ activation by its ligands, there are only a few reports considering their effect on PPARG expression. The regulation mechanism of PPARG transcription has been extensively studied and can be associated with numerous factors. However, the vast majority of available data focus on the regulation of $P P A R G$ expression in adipose tissue (where it acts as a crucial regulator of adipocytes differentiation), and this mechanism in other cells still remains elusive $[32,33]$. The previous research presented by $\mathrm{Lu}$ et al., focused on hepatocellular carcinoma, motivated us to investigate the CLA potential to upregulate PPARG expression level in LC [8]. In our present study, we focused on the impact of c9,t11 CLA, which is an activator of PPAR- $\gamma$ protein, on PPAR- $\gamma$ transcript and protein levels in NSCLC cells and in normal human bronchial epithelial cell line. Similar to Lu et al. results we 
A
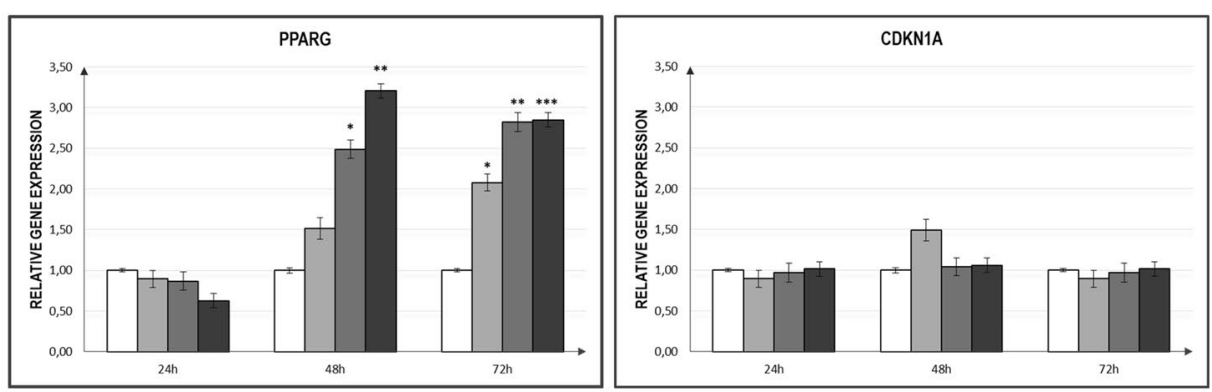

BEAS 2B
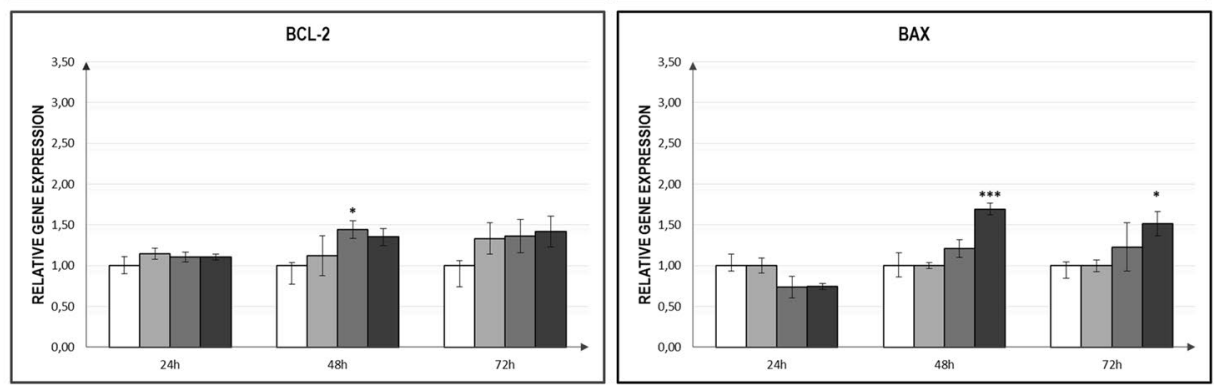

Control

$25 \mu \mathrm{M}$ CLA

$50 \mu \mathrm{M}$ CLA

$75 \mu \mathrm{M}$ CLA
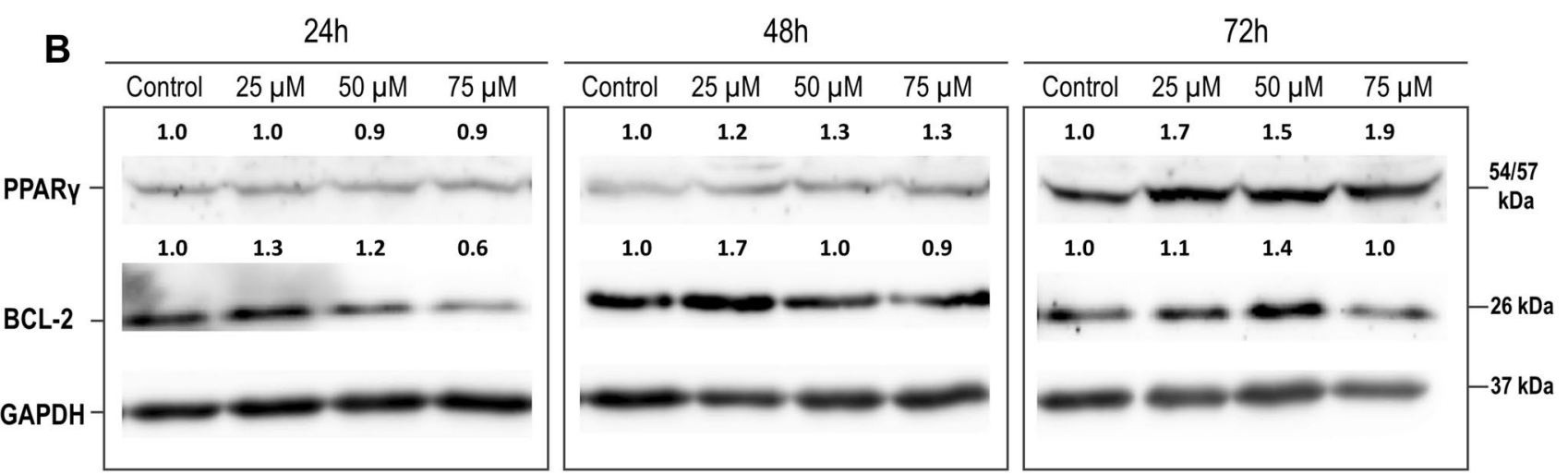

Fig. 3 a Relative expression levels of $P P A R G, C D K N 1 A, B C L-2$ and $B A X$ genes in the Beas-2B cell line, after treatment with different doses of c9, t11 CLA in selected incubation times. Cells were maintained for $24 \mathrm{~h}$ to $72 \mathrm{~h}$ in the absence (controls) or in the presence of c9, t11 CLA at concentrations of 25, 50 and $75 \mu \mathrm{M}$. After incubation, cells were used for total RNA isolation and RT-qPCR analysis. Each gene transcript level is displayed as the mean multiplicity of the respective control samples \pm SEM. Statistically significant differences between control and tested samples are marked with asterisks (* $p$ value $<0.05$; ** $p$ value $<0.01$; and $*^{* *} p$ value $\left.<0.001\right)$. b Repre-

showed that in all investigated cell types, c9,t11 CLA was able to significantly elevate PPAR- $\gamma$ mRNA and protein levels. This effect was most noticeable in Beas-2B and A549 cells. We did not find any previous research that describes a similar phenomenon in normal lung cells or NSCLC cell lines. However, aforementioned study performed by $\mathrm{Lu}$ et al. demonstrated that both PPAR- $\gamma$ transcript and protein levels could be enhanced by c9,t11 CLA in human hepatocellular carcinoma cell lines [8]. In addition, research presented by Ramiah et al. showed that PPARG mRNA level can be upregulated in the liver of chickens fed by CLA [34]. Together, these results confirm that this particular isomer of sentative image of Western Blot analysis of PPAR- $\gamma$ and BCL-2 status in Beas-2B cell line. Cells were maintained for $24 \mathrm{~h}$ to $72 \mathrm{~h}$ in the absence (controls, only DMSO) or in the presence of c9, t11 CLA at concentrations of 25,50 and $75 \mu \mathrm{M}$. Proteins were isolated by using RIPA buffer, separated by $10 \%$ SDS-PAGE and detected by Western Blotting. The numbers above the images of protein bands are optical density ratio values of PPAR- $\gamma$ or BCL-2 to GAPDH for each sample. The ratio of PPAR- $\gamma$ or BCL-2 to GAPDH for control cells in each incubation time was assumed to be 1 . The protein level was displayed as the mean multiplicity of the respective control sample

linoleic acid is not only an activator of PPAR- $\gamma$ protein but can also act as a positive regulator of its expression.

It is also worth emphasizing that the application of c9,t11 CLA, and the subsequent increase in PPAR- $\gamma$ in Lu's et al. investigation, were associated with a strong apoptotic response mediated by changes in the level of apoptosis-related proteins, mainly by upregulation of BAX and/ or downregulation of BCL-2 at both, mRNA and protein levels, which resulted in disturbances in the BAX/BCL-2 ratio [8]. This anticancer effect triggered by CLA is corroborated by ample research $[7,9,10,29$. The Activation of PPAR $\gamma$ can induce apoptosis in several different ways which 
Table 3 Statistical analysis of PPARG, BCL-2, BAX and CDKN1A expression level in control and c9, t11 CLA-treated Beas-2B cells in different times of incubation; $p$ value $<0.05$ was considered statistically significant

\begin{tabular}{|c|c|c|c|c|c|c|}
\hline \multirow[t]{3}{*}{ Cell line/gene } & \multirow{3}{*}{$\begin{array}{l}\text { Time of incu- } \\
\text { bation }\end{array}$} & \multicolumn{5}{|l|}{ Beas- $2 b$} \\
\hline & & \multicolumn{5}{|c|}{ Relative normalized expression } \\
\hline & & Control $( \pm$ SEM $)$ & $25 \mathrm{uM}( \pm$ SEM $)$ & $50 \mathrm{uM}( \pm \mathrm{SEM})$ & $75 \mathrm{uM}( \pm \mathrm{SEM})$ & ANOVA $p$ value \\
\hline \multirow[t]{6}{*}{$P P A R G$} & $24 \mathrm{~h}$ & 1.00 & 0.89 & 0.87 & 0.63 & $>0.5$ \\
\hline & & $( \pm 0.06)$ & $( \pm 0.22)$ & $( \pm 0.14)$ & $( \pm 0.05)$ & \\
\hline & $48 \mathrm{~h}$ & 1.00 & 1.52 & $2.49^{*}$ & $3.21^{* *}$ & 0.0016 \\
\hline & & $( \pm 0.11)$ & $( \pm 0.23$ & $( \pm 0.41)$ & $( \pm 0.23)$ & \\
\hline & $72 \mathrm{~h}$ & 1.00 & $2.08^{*}$ & $2.82^{* *}$ & $2.85^{* * *}$ & 0.0015 \\
\hline & & $( \pm 0.09)$ & $( \pm 0.39)$ & $( \pm 0.22)$ & $( \pm 0.09)$ & \\
\hline \multirow[t]{6}{*}{$B C L-2$} & $24 \mathrm{~h}$ & 1.00 & 1.14 & 1.11 & 1.11 & $>0.5$ \\
\hline & & $( \pm 0.11)$ & $( \pm 0.07)$ & $( \pm 0.06)$ & $( \pm 0.04)$ & \\
\hline & $48 \mathrm{~h}$ & 1.00 & 1.12 & $1.44^{*}$ & 1.35 & 0.0195 \\
\hline & & $( \pm 0.04)$ & $( \pm 0.24)$ & $( \pm 0.11)$ & $( \pm 0.10)$ & \\
\hline & $72 \mathrm{~h}$ & 1.00 & 1.33 & 1.36 & 1.42 & $>0.5$ \\
\hline & & $( \pm 0.06)$ & $( \pm 0.19)$ & $( \pm 0.20)$ & $( \pm 0.19)$ & \\
\hline \multirow[t]{6}{*}{$B A X$} & $24 \mathrm{~h}$ & 1.00 & 0.79 & 0.74 & 0.74 & $>0.5$ \\
\hline & & $( \pm 0.14)$ & $( \pm 0.09)$ & $( \pm 0.13)$ & $( \pm 0.04)$ & \\
\hline & $48 \mathrm{~h}$ & 1.00 & 0.75 & 1.21 & $1.69^{* * *}$ & 0.0001 \\
\hline & & $( \pm 0.16)$ & $( \pm 0.04$ & $( \pm 0.11$ & $( \pm 0.07)$ & \\
\hline & $72 \mathrm{~h}$ & 1.00 & 0.90 & 1.23 & $1.51^{*}$ & 0.0103 \\
\hline & & $( \pm 0.05)$ & $( \pm 0.07)$ & $( \pm 0.30)$ & $( \pm 0.15)$ & \\
\hline \multirow[t]{6}{*}{ CDKN1A } & $24 \mathrm{~h}$ & 1.00 & 0.90 & 0.97 & 1.01 & $>0.5$ \\
\hline & & $( \pm 0.02)$ & $( \pm 0.11)$ & $( \pm 0.12$ & $( \pm 0.09)$ & \\
\hline & $48 \mathrm{~h}$ & 1.00 & 1.20 & 1.04 & 1.06 & $>0.5$ \\
\hline & & $( \pm 0.03)$ & $( \pm 0.13)$ & $( \pm 0.11)$ & $( \pm 0.09)$ & \\
\hline & $72 \mathrm{~h}$ & 1.00 & 0.90 & 0.97 & 1.01 & $>0.5$ \\
\hline & & $( \pm 0.02)$ & $( \pm 0.11)$ & $( \pm 0.12)$ & $( \pm 0.09)$ & \\
\hline
\end{tabular}

Asterisk marked results significantly differs compared to untreated control—samples measurements $(* p$ value $<0.05 ; * * p$ value $<0.01 ; * * * p$ value $<0.001$ )

are thoroughly described by Elrod et al. [18]. In one of the signalling pathways, PPAR- $\gamma$ is able to bind to the nuclear NF- $\kappa \mathrm{B}$ factor site, located in the promoter sequences of TP53, thus enhancing its expression [35]. Additionally, it has been shown, that some PPAR $\gamma$ ligands (especially thiazolidinediones) enhance the recruitment of PPAR $\gamma$ to the TP53 promoter [36]. Consequently, the p53 protein is responsible for the transcriptional activation of several apoptosis-related genes i.e. $B A X$ or $D R 5$ [37].

In our work we obtained a cellular response leading to an upregulation of $P P A R G$ in all investigated cell lines, but $B A X$ expression was only induced in normal bronchial epithelial cells. Surprisingly, we noticed an elevation of antiapoptotic $B C L-2$ gene expression at both mRNA and protein level in investigated NSCLC cells. However, the results of MTT assay depicted that CLA is an effective compound that inhibits NSCLC cells proliferation. The higher doses and/ or longer incubation periods with CLA, the more prominent growth inhibition of treated cells was observed, compared to the respective controls. The fluorescent staining confirmed, that $\mathrm{c} 9, \mathrm{t} 11$ CLA isomer can cause cell death and lead to limited cell proliferation. After CLA treatment we observed differences of cell morphology between exposed and control cells. We also detected the PI-derived red fluorescent signal emitted by cells incubated with high doses of mentioned compound, which is an evidence of disturbed membrane permeability. These results, together with an increased expression of $P P A R G$ may suggest that CLA can cause cells death trough PPAR- $\gamma$ dependant mechanism. However, we cannot clarify whether this process is associated with the BAX pathway, as in our experiments we did not observe an upregulation of $B A X \mathrm{mRNA}$ level. Conversely, we detected an increased expression of $B C L-2$. Similar results were presented in the research performed by Majumder and co-workers. They investigated the influence of CLA on key apoptotic genes in human breast cancer cells and noticed that $B C L$ 2 transcripts were significantly elevated in MDA-MB-231 cells after CLA stimulation. Nevertheless, in those cells 


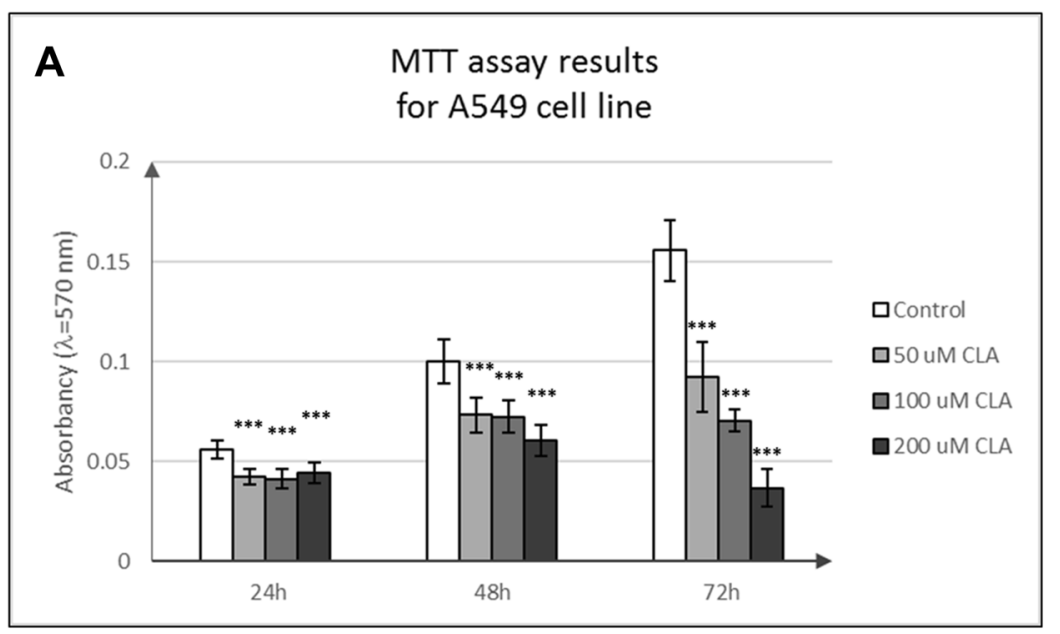

\begin{tabular}{|c|c|c|c|c|}
\hline $24 \mathrm{~h}$ & Control & $50 \mu \mathrm{M}$ & $100 \mu \mathrm{M}$ & $200 \mu \mathrm{M}$ \\
\hline Control & & $P<0.001$ & $P<0.001$ & $P<0.001$ \\
\hline $50 \mu \mathrm{m}$ & & & $P>0.05$ & $P>0.05$ \\
\hline $100 \mu \mathrm{M}$ & & & & $P>0.05$ \\
\hline $200 \mu \mathrm{M}$ & & & & \\
\hline
\end{tabular}

\begin{tabular}{|c|c|c|c|c|}
\hline $48 \mathrm{~h}$ & Control & $50 \mu \mathrm{M}$ & $100 \mu \mathrm{M}$ & $200 \mu \mathrm{M}$ \\
\hline Control & & $P<0.001$ & $P<0.001$ & $P<0.001$ \\
\hline $50 \mu \mathrm{M}$ & & & $P>0.05$ & $P<0.05$ \\
\hline $100 \mu \mathrm{M}$ & & & & $P<0.05$ \\
\hline \multicolumn{5}{|l|}{$200 \mu \mathrm{M}$} \\
\hline $72 \mathrm{~h}$ & Control & $50 \mu \mathrm{M}$ & $100 \mu \mathrm{M}$ & $200 \mu \mathrm{M}$ \\
\hline Control & & $P<0.001$ & $P<0.001$ & $P<0.001$ \\
\hline $50 \mu \mathrm{M}$ & & & $P>0.05$ & $P<0.001$ \\
\hline $100 \mu \mathrm{M}$ & & & & $P<0.05$ \\
\hline $200 \mu \mathrm{M}$ & & & & \\
\hline
\end{tabular}

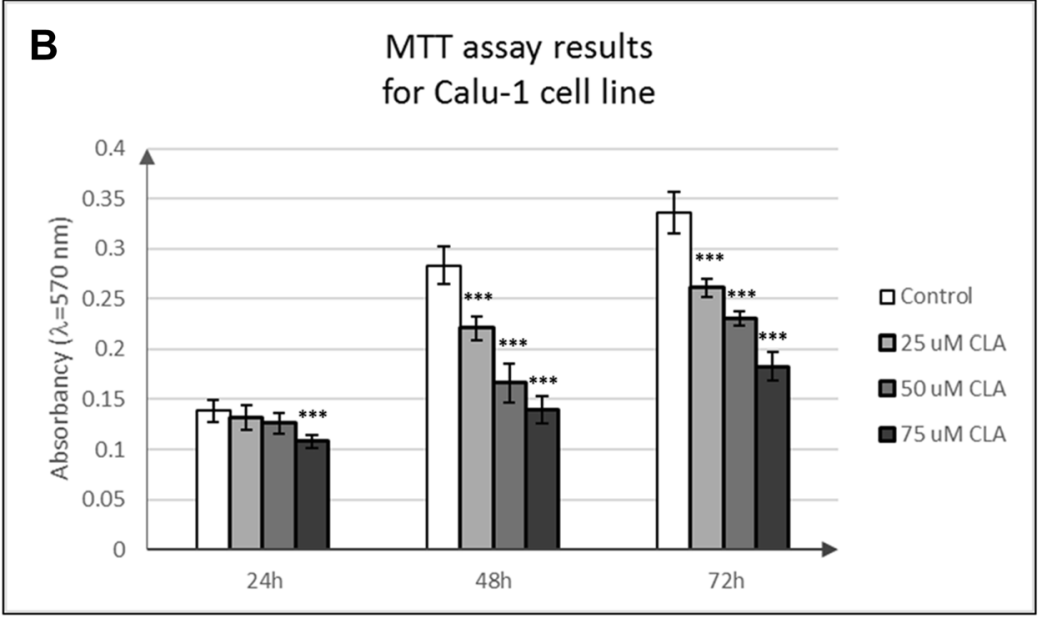

\begin{tabular}{|c|c|c|c|c|}
\hline $24 \mathrm{~h}$ & Control & $25 \mu \mathrm{M}$ & $50 \mu \mathrm{M}$ & $75 \mu \mathrm{M}$ \\
\hline Control & & $P>0.05$ & $P>0.05$ & $P<0.001$ \\
\hline $25 \mu \mathrm{M}$ & & & $P>0.05$ & $P<0.01$ \\
\hline $50 \mu \mathrm{M}$ & & & & $P<0.05$ \\
\hline \multicolumn{5}{|l|}{$75 \mu \mathrm{M}$} \\
\hline $48 \mathrm{~h}$ & Control & $25 \mu \mathrm{M}$ & $50 \mu \mathrm{M}$ & $75 \mu \mathrm{M}$ \\
\hline Control & & $P<0.001$ & $P<0.001$ & $P<0.001$ \\
\hline $25 \mu \mathrm{M}$ & & & $P<0.001$ & $P<0.001$ \\
\hline $50 \mu \mathrm{M}$ & & & & $P<0.05$ \\
\hline \multicolumn{5}{|l|}{$75 \mu \mathrm{M}$} \\
\hline $72 \mathrm{~h}$ & Control & $25 \mu \mathrm{M}$ & $50 \mu \mathrm{M}$ & $75 \mu \mathrm{M}$ \\
\hline Control & & $P<0.001$ & $P<0.001$ & $P<0.001$ \\
\hline $25 \mu \mathrm{M}$ & & & $P<0.01$ & $P<0.001$ \\
\hline $50 \mu \mathrm{M}$ & & & & $P<0.001$ \\
\hline $75 \mu \mathrm{M}$ & & & & \\
\hline
\end{tabular}

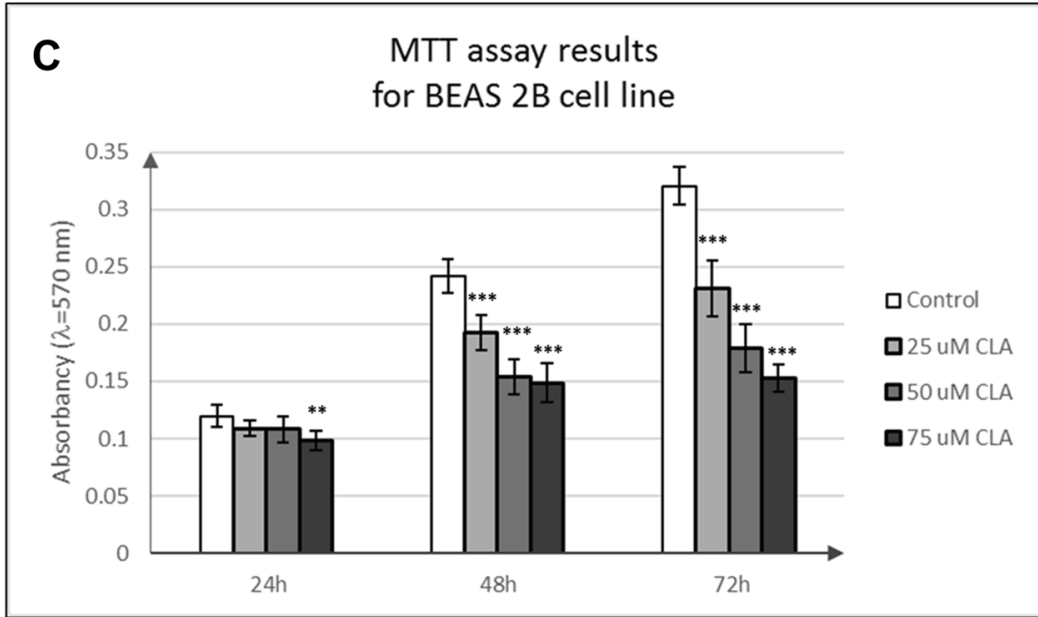

\begin{tabular}{|c|c|c|c|c|}
\hline $24 \mathrm{~h}$ & Control & $25 \mu \mathrm{M}$ & $50 \mu \mathrm{M}$ & $75 \mu \mathrm{M}$ \\
\hline Control & & $P>0.05$ & $P>0.05$ & $P<0.01$ \\
\hline $25 \mu \mathrm{M}$ & & & $P>0.05$ & $P>0.05$ \\
\hline $50 \mu \mathrm{M}$ & & & & $P>0.05$ \\
\hline \multicolumn{5}{|l|}{$75 \mu \mathrm{M}$} \\
\hline $48 \mathrm{~h}$ & Control & $25 \mu \mathrm{M}$ & $50 \mu \mathrm{M}$ & $75 \mu \mathrm{M}$ \\
\hline Control & & $P<0.001$ & $P<0.001$ & $P<0.001$ \\
\hline $25 \mu \mathrm{M}$ & & & $P<0.001$ & $P<0.001$ \\
\hline $50 \mu \mathrm{M}$ & & & & $P>0.05$ \\
\hline \multicolumn{5}{|l|}{$75 \mu \mathrm{M}$} \\
\hline $72 \mathrm{~h}$ & Control & $25 \mu \mathrm{M}$ & $50 \mu \mathrm{M}$ & $75 \mu \mathrm{M}$ \\
\hline Control & & $P<0.001$ & $P<0.001$ & $P<0.001$ \\
\hline $25 \mu \mathrm{M}$ & & & $P<0.001$ & $P<0.001$ \\
\hline $50 \mu \mathrm{M}$ & & & & $P>0.05$ \\
\hline $75 \mu \mathrm{M}$ & & & & \\
\hline
\end{tabular}

Fig. 4 Effect of different doses of CLA on the proliferation of A549 (a), Calu-1 (b) and Beas-2B (c) cells. Statistically significant differences between control and tested samples are marked with asterisks $\left({ }^{*} p\right.$ value $<0.05 ; * *$ value $<0.01$; and $* * * p$ value $<0.001$ )

CLA was also able to elevate the amount of pro-apoptotic BAX and BCL-XS proteins, which resulted in a higher ratio of these proteins to BCL-2 and promoted cell apoptosis [38]. Unfortunately, the content of BAX protein in investigated NSCLC cells was not assessed in our work, which leaves the open door for further research. Moreover, there are studies showing that, PPAR- $\gamma$ and p53 proteins are involved in triggering cell apoptosis trough other mechanisms, like the DNA fragmentation and caspase-9 pathway [39] 

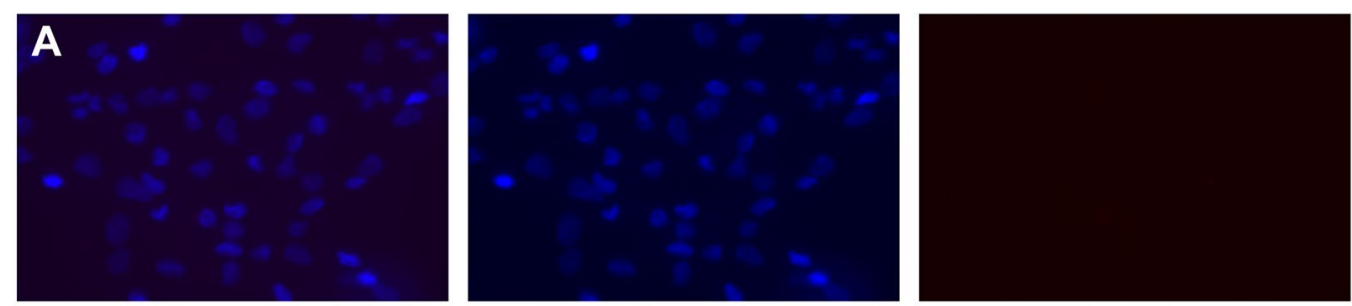

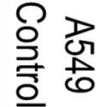
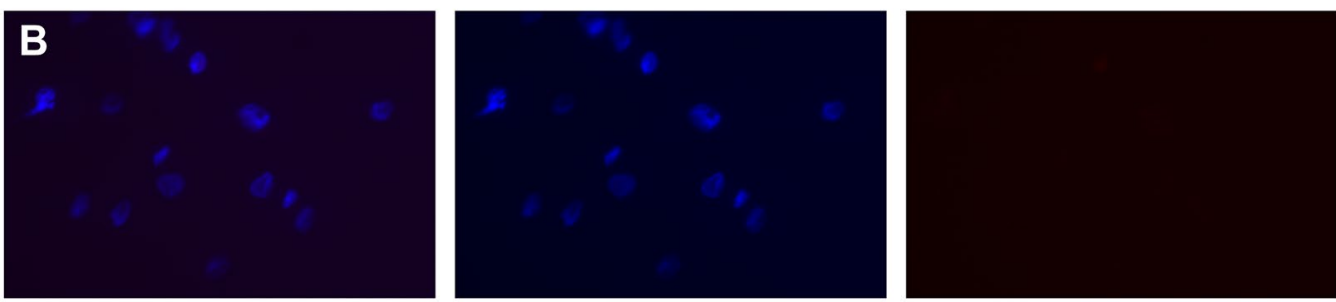

N

G

당

$\Omega$ है
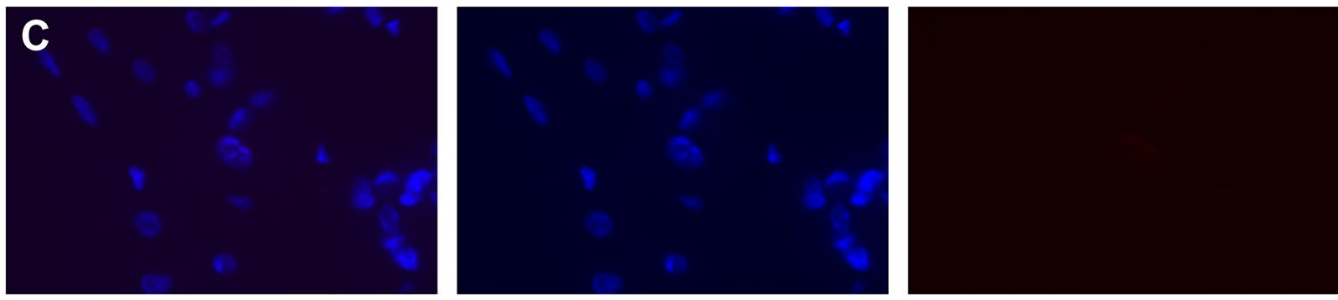

당

당

ती

D
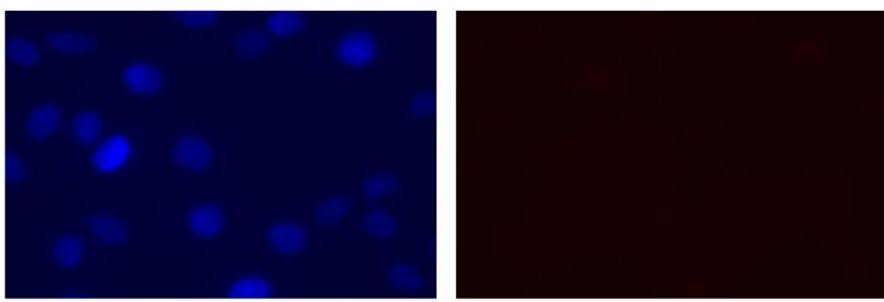

ज

난

$\Omega$

$\Gamma^{5}$
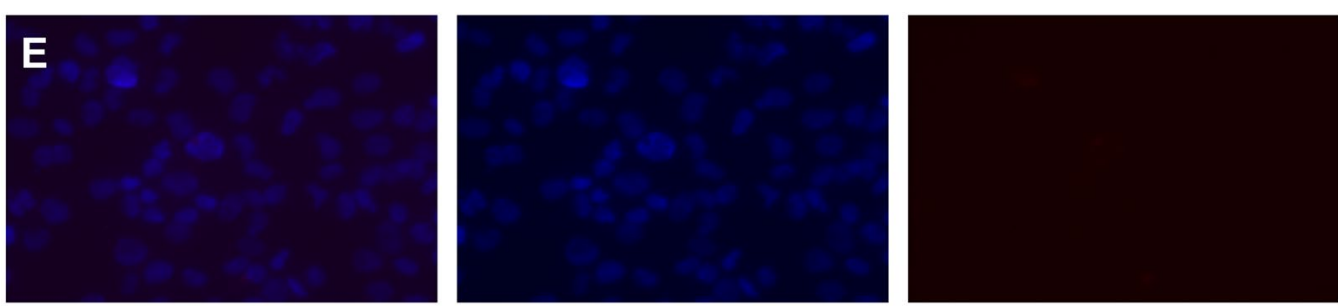

$\vec{\varnothing}$

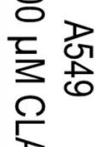
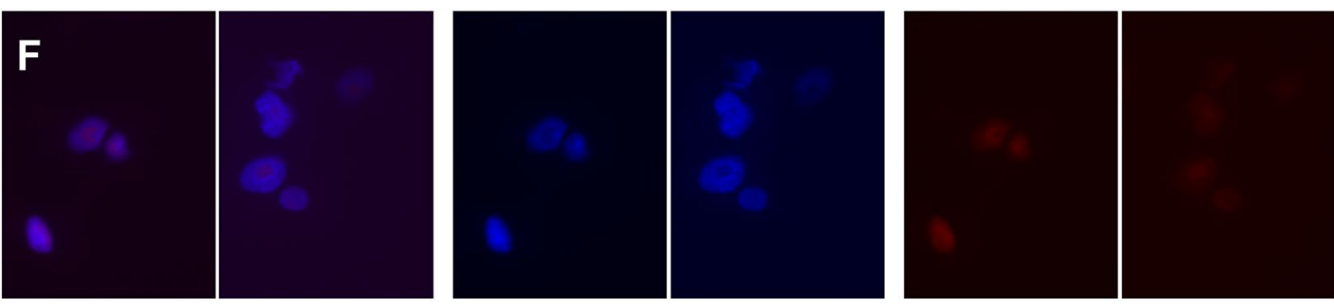

$\overrightarrow{\mathrm{g}}$

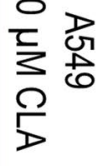

G
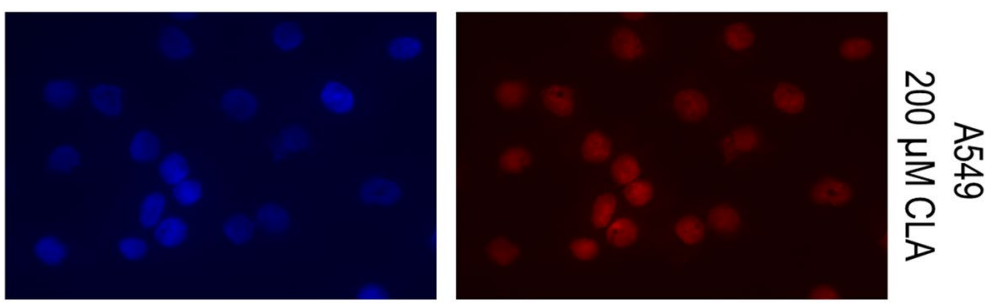

Merged

Hoechst 33342

PI 
4Fig. 5 Double, fluorescent staining of A549 cells with Hoechst 33,342 $(1 \mu \mathrm{g} / \mathrm{ml})$ and PI $(1 \mu \mathrm{g} / \mathrm{ml})$ - a control (CLA-untreated, DMSO-treated cells); b cells treated with $25 \mu \mathrm{M}$ CLA; c cells treated with $50 \mu \mathrm{M}$ CLA; d cells treated with $75 \mu \mathrm{M}$ CLA; e cells treated with $100 \mu \mathrm{M}$ CLA; f cells treated with $150 \mu \mathrm{M}$ CLA; $\mathbf{g}$ cells treated with $200 \mu \mathrm{M}$ CLA. Fluorescent signal was detected by fluorescence microscope magnification $=\times 40$

In recent studies, it has also been shown that the increased quantity of ligand-activated PPAR- $\gamma$ can act as a protective, anti-apoptotic factor by an upregulation of the BCL-2 protein level [22-24, 40, 41]. This effect was achieved through the application of thiazolidinediones [40] (especially rosiglitazone [22, 23, 41]) and prostaglandins [42], which are also strong PPAR- $\gamma$ agonists. The authors emphasize the crucial role of PPAR- $\gamma$ in the cellular defence against oxidative stress, ischaemia or stroke, especially in neural and cardiac cells. Nevertheless, Fong et al. indicated that the mechanism of this effect remains elusive. These findings suggest that cellular effects exerted by PPAR- $\gamma$ may be different in various types of cells. It is important to mention that the concentration of stimulant may be not without significance concerning the pro- or anti-apoptotic role of PPAR- $\gamma$ [24].

Another interesting report draws attention to the PPAR- $\gamma$ status in primary NSCLC tissues, highlighting that the expression level of PPARG in lung tumours is usually considerably higher in comparison to corresponding histopathologically unchanged samples, however, this intratumoural PPARG overexpression does not exhibit an anticarcinogenic/ protective effect because of the lack of PPAR- $\gamma$ agonists [43, 44]. Li and co-workers proved that the addition of PPAR- $\gamma$ activating ligand (troglitazone) lead to an inhibition of lung cancer cells proliferation, previously induced by carcinogenic chemicals of cigarette smoke [44]. In the light of these results, CLA appears to be a potent anticancer agent, as it not only elevates the expression of PPAR- $\gamma$, but it also acts as its ligand, contributing to decreased NSCLC cells proliferation. In our study, we also analysed the changes in the expression of the CDKN1A gene, encoding a cyclin-dependent kinase inhibitor, p21, which is a key factor participating in cell cycle control and arrest. Previous studies reported the inducing effect of PPAR- $\gamma$ activators on p21 expression in colon and lung cancer cell lines [45-48]. It was shown that the PPAR- $\gamma$ ligands (PGJ2 and ciglitazone) inhibited the growth and induced apoptosis of several lung carcinoma cell lines. Those processes were mediated by an induction of CDKN1A gene expression [46]. In addition, the progression of colon cancer cells was also inhibited after treatment with physiological concentrations of CLA, which was connected with an upregulation of p21 [45]. Although, we clearly demonstrated that CLA induces the mRNA and protein content of PPAR- $\gamma$ in A549, Calu-1 and Beas-2B cells, we did not detect any significant changes concerning $C D K N 1 A$ transcript levels. A small upregulation of $C D K N 1 A$ expression occurred only in Calu- 1 cell line at the dose of $75 \mu \mathrm{M}$ of CLA. It is worth to mention that the transcriptional regulation of $C D K N 1 A$ is a complex process. Han et al. showed that in case of PPAR- $\gamma$ ligands such as PGJ2 and ciglitazone there was an enhanced binding activity of $\mathrm{Sp} 1$ and $\mathrm{C} / \mathrm{EBP}$ transcription factors sites in the promoter region of $C D K N 1 A$, which led to its overexpression [46]. On the other hand, there are also works that pinpointed that the expression of some genes is diminished by PPAR- $\gamma$ ligands, as in this situation they negatively regulate the binding activity of the same transcription factors (Sp1 and C/EBP) [49, 50].Thus, the influence of PPAR- $\gamma$ ligands concerning gene expression issue may be cell type specific. On the other hand, Miller et al. demonstrated that the induction of p21 is rapid and does not last long. In their study, the strongest increase in $\mathrm{p} 21$ protein and transcript levels was observed after $6 \mathrm{~h}$ of incubation with PPAR- $\gamma$ activator; however, after $24 \mathrm{~h}$, this effect diminished [51]. As our shortest incubation period with CLA was $24 \mathrm{~h}$, it is possible that we could omit any possible changes in $C D K N 1 A$ mRNA level. In conclusion, we showed for the first time that c9,t11 CLA can significantly induce PPARG expression in NSCLC and in normal human bronchial epithelial cells. We also showed that the inhibition of NSCLC cell proliferation mediated by CLA may be connected with its stimulatory effect triggered on PPAR- $\gamma$. However, there are many pathways activated by PPAR- $\gamma$ that can lead to the cell growth arrest and apoptosis. Moreover, the apoptotic response can differ depending on various factors, i.e. type of tissue or cell line, or the type and concentration of PPAR- $\gamma$ activator. We were able to demonstrate that apart from the induction of PPARG expression in investigated cell lines, CLA definitely exerts antiproliferative effect and causes prompt morphological changes in our cells (cytoplasmic vacuolization and appearance of enlarged cells with micronuclei). Thus, our study supports the proven antiproliferative and anticancer potential of CLA. However, we want to point out that the effect exerted by the CLA also concerned the normal human bronchial epithelial cells (Beas-2B), which is worth considering in terms of the safety of using this compound. Is CLA a noteworthy prophylactic or protective agent? Ample research supports this idea, and we are not going to question it. What is more important, the precise mechanism that lead to an inhibition of cell proliferation after CLA treatment, alongside PPARG overexpression in NSCLC cells need to be further clarified. 

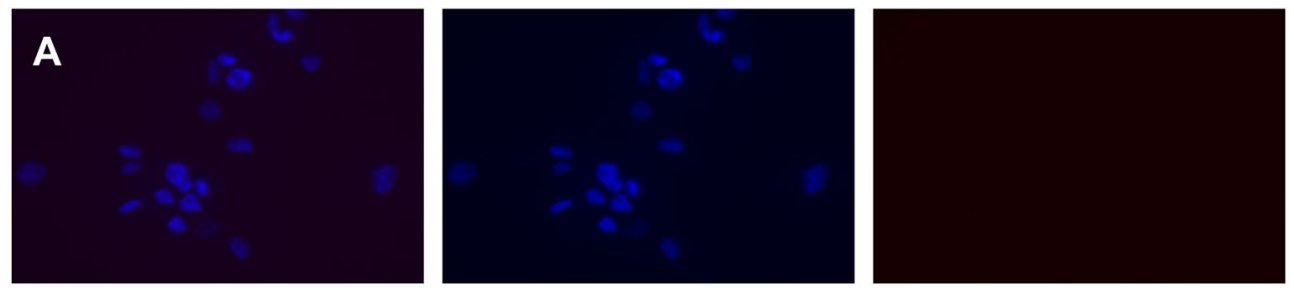

\section{올
홓
으}

B
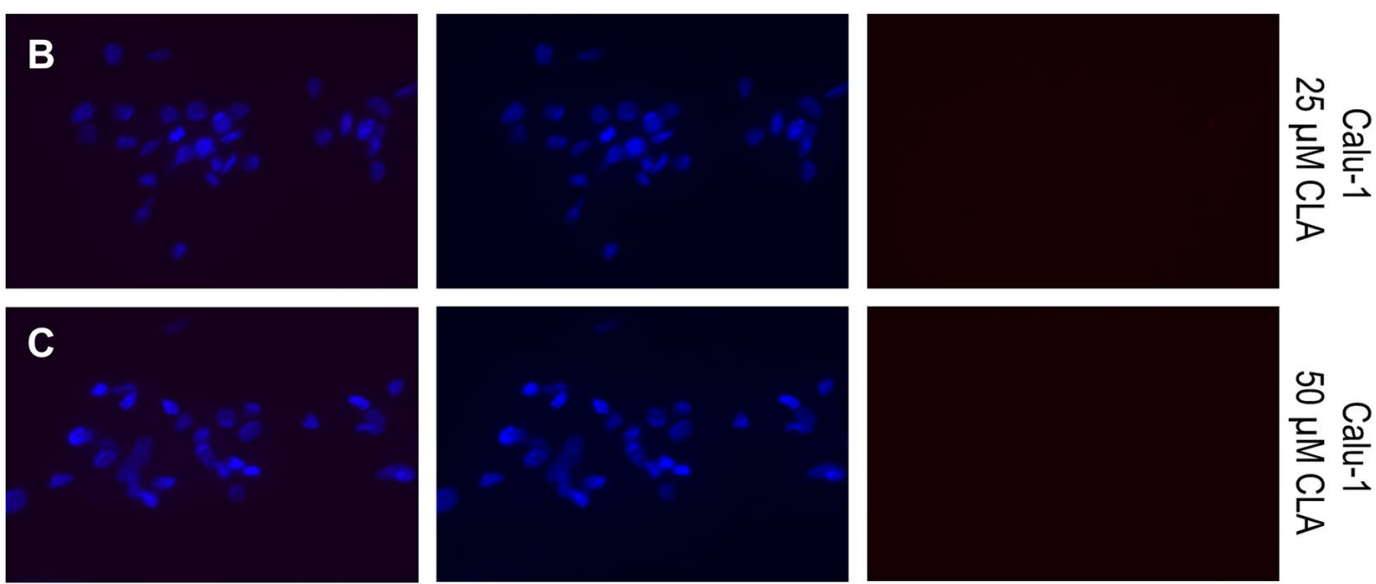

\section{당 \\ 京}
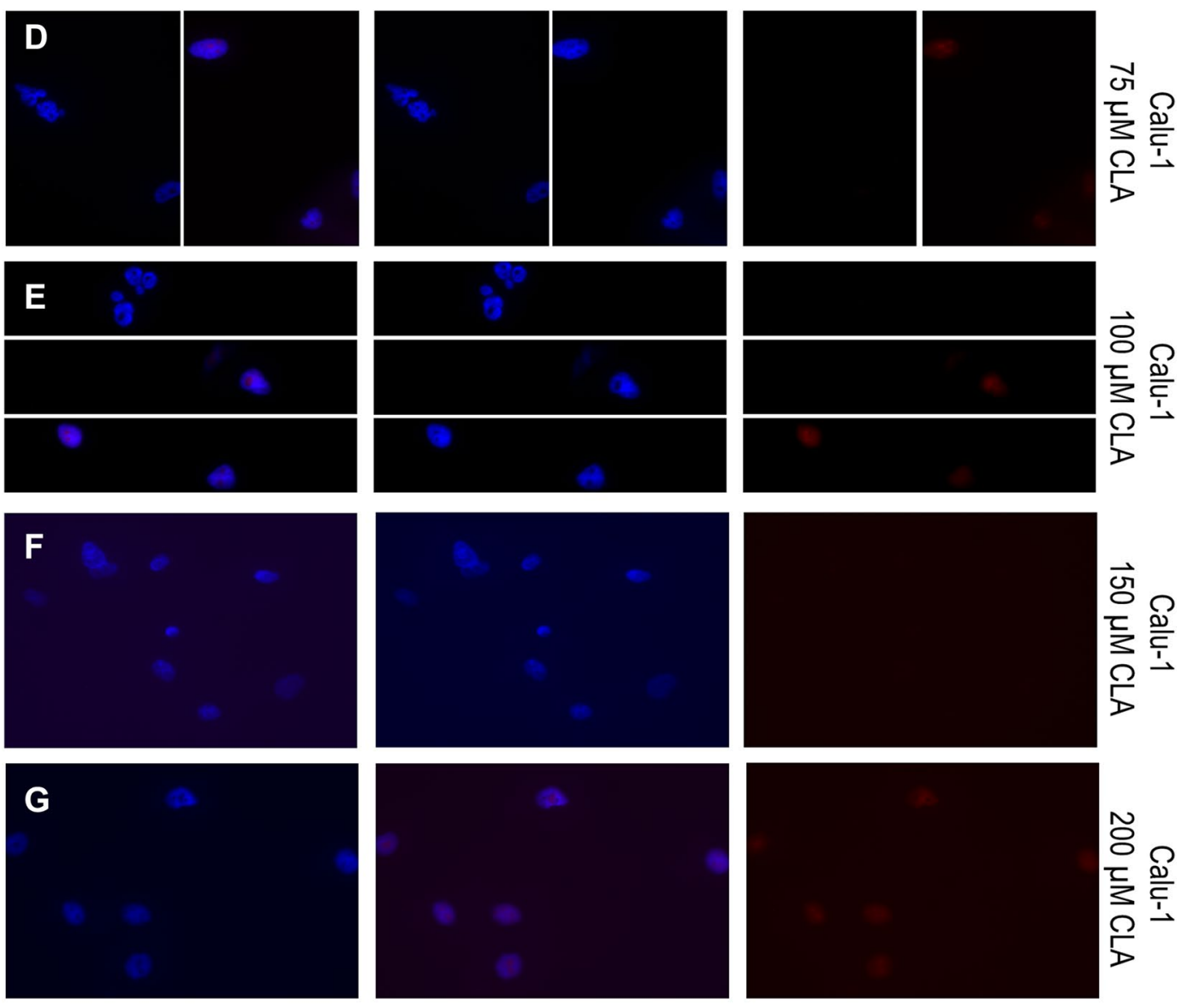

Merged

Hoechst 33342

PI

Fig. 6 Double, fluorescent staining of Calu-1 cells with Hoechst 33,342 $(1 \mu \mathrm{g} / \mathrm{ml})$ and PI $(1 \mu \mathrm{g} / \mathrm{ml})$ - a control (CLA-untreated, DMSO-treated cells); b cells treated with $25 \mu \mathrm{M}$ CLA; c cells treated with $50 \mu \mathrm{M}$ CLA; d cells treated with $75 \mu \mathrm{M}$ CLA; e cells treated with $100 \mu \mathrm{M}$ CLA; $\mathbf{f}$ cells treated with $150 \mu \mathrm{M}$ CLA; $\mathbf{g}$ cells treated with $200 \mu \mathrm{M}$ CLA. Fluorescent signal was detected by fluorescence microscope magnification $=\times 40$ 

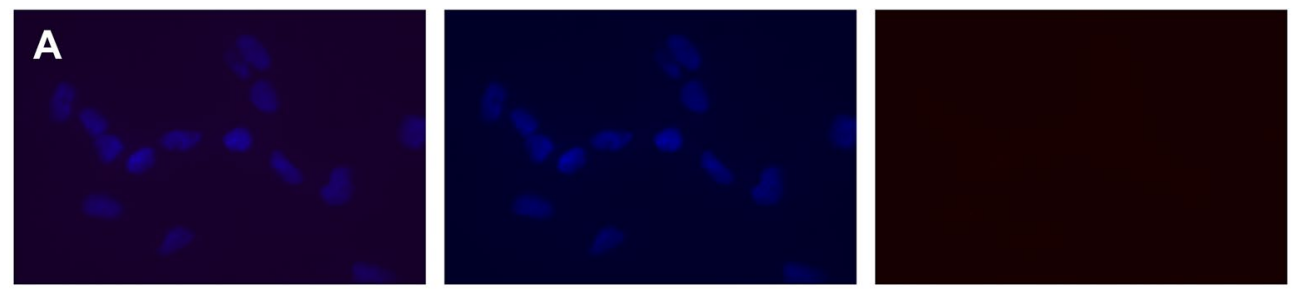

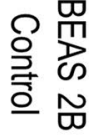
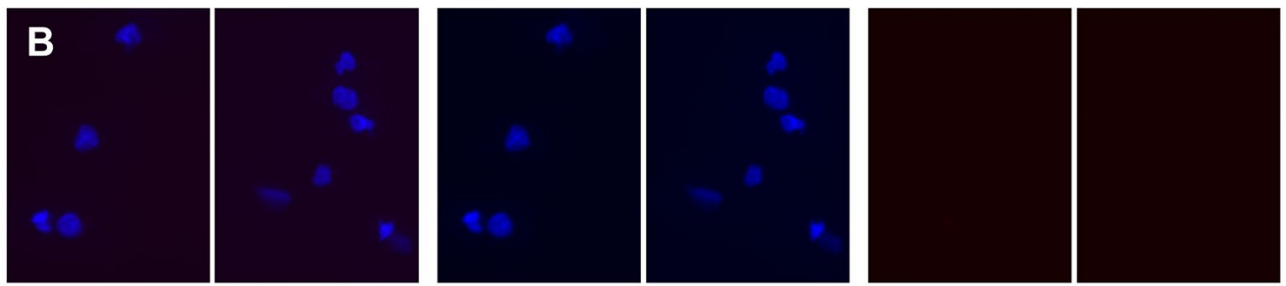

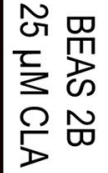
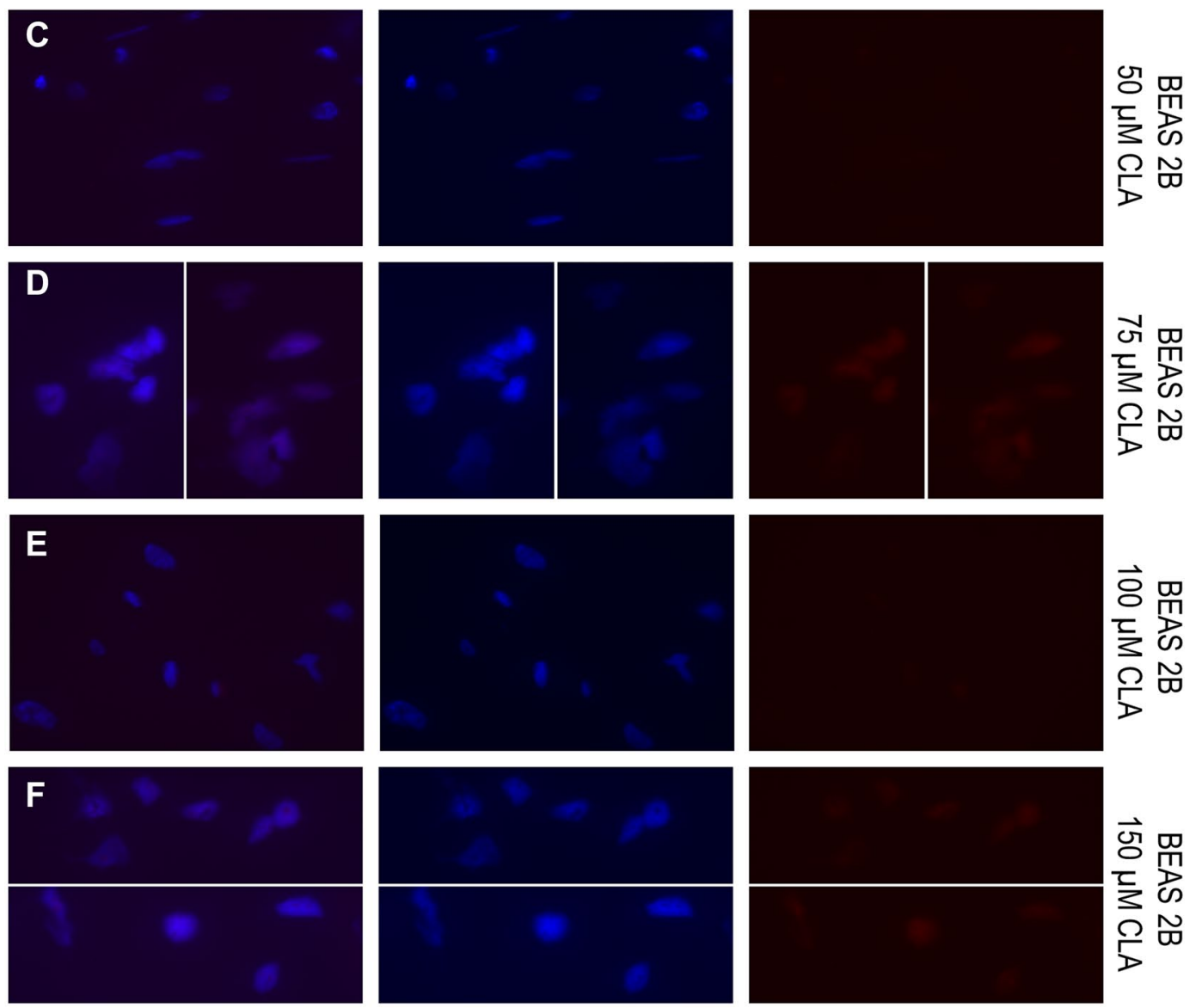

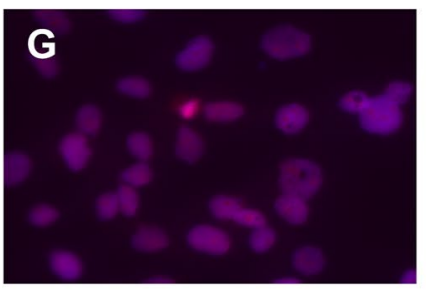

Merged

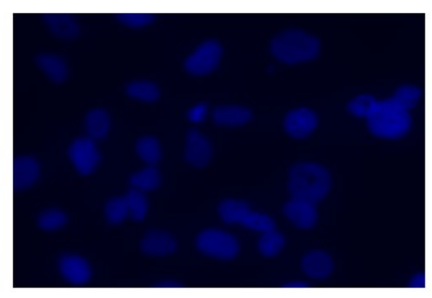

Hoechst 33342

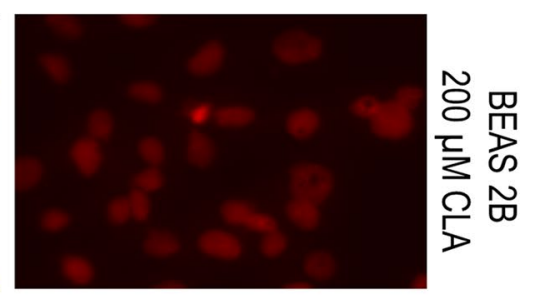

PI
Fig. 7 Double, fluorescent staining of Beas-2B cells with Hoechst 33,342 (1 $\mu \mathrm{g} / \mathrm{ml})$ and PI $(1 \mu \mathrm{g} / \mathrm{ml})$ - a control (CLA-untreated, DMSO-treated cells); b cells treated with $25 \mu \mathrm{M}$ CLA; c cells treated with $50 \mu \mathrm{M}$ CLA; d cells treated with $75 \mu \mathrm{M}$ CLA; e cells treated with $100 \mu \mathrm{M}$ CLA; $\mathbf{f}$ cells treated with $150 \mu \mathrm{M}$ CLA; $\mathbf{g}$ cells treated with $200 \mu \mathrm{M}$ CLA. Fluorescent signal was detected by fluorescence microscope magnification $=\times 40$ 

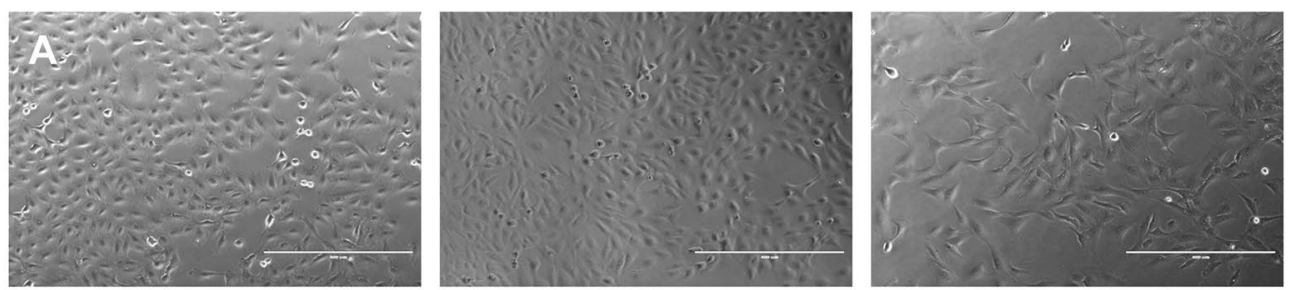

을
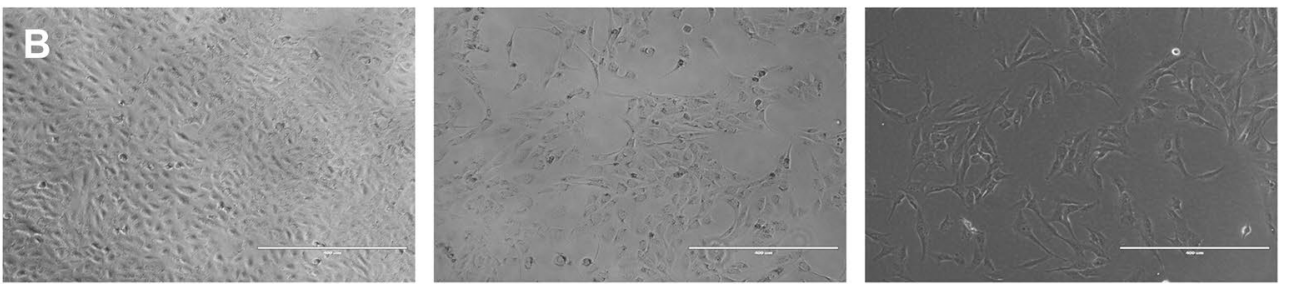

ज
$\frac{5}{5}$
$\frac{2}{D}$
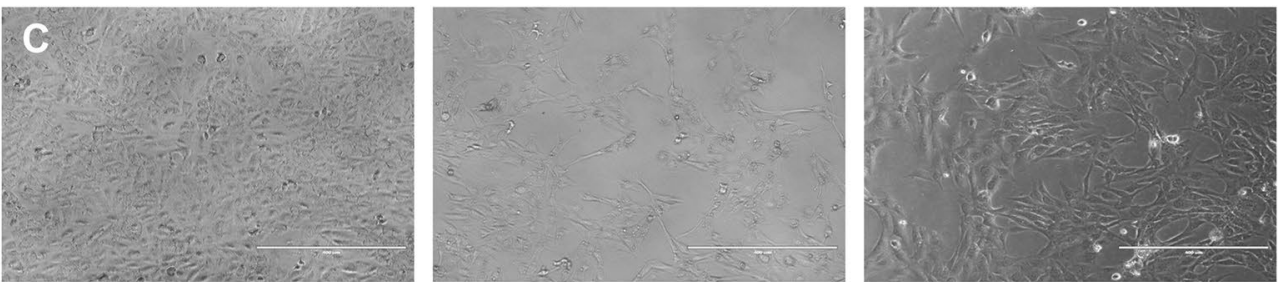

응
$\frac{1}{3}$
$\frac{0}{5}$
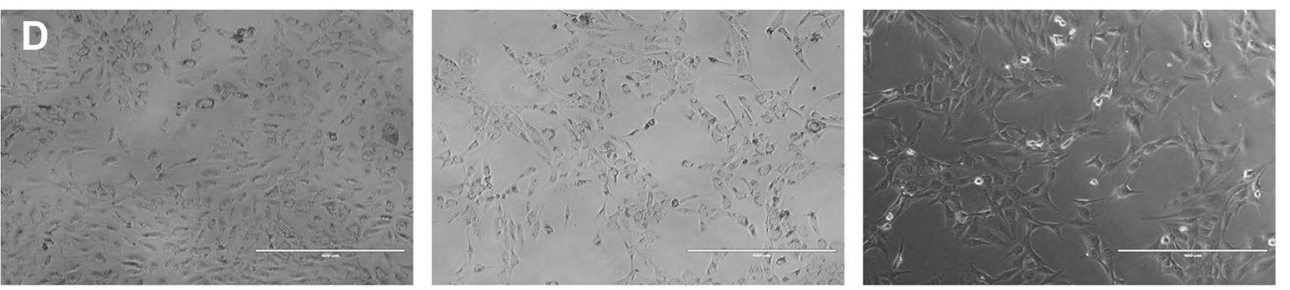

जे
$\frac{5}{5}$
$\frac{1}{5}$
5
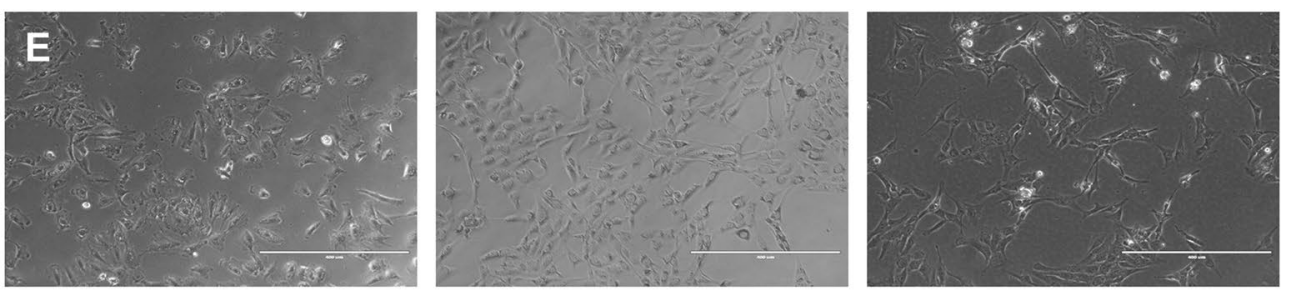

$\overrightarrow{8}$
$\frac{5}{3}$
$\frac{1}{5}$
$\frac{1}{7}$
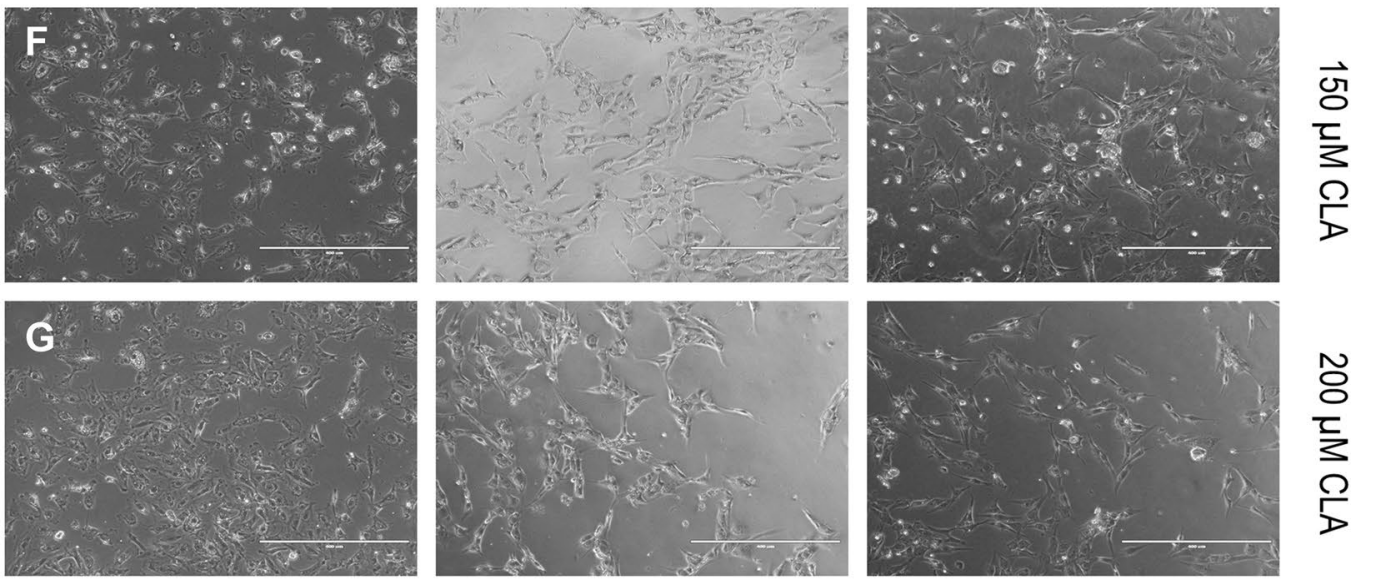

A549

Calu-1

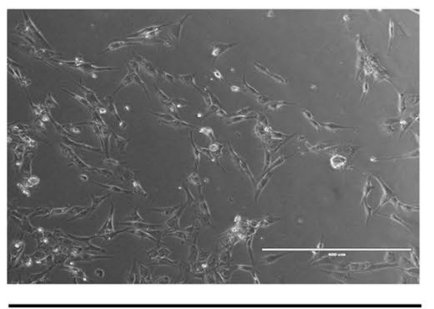

O
$\frac{1}{3}$
$\frac{2}{5}$
$\frac{1}{5}$

Fig. 8 Standard microscopic picture of A549, Calu-1 and Beas-2B cell after CLA treatment - a control (CLA-untreated, DMSO-treated cells); b cells treated with $25 \mu \mathrm{M}$ CLA; c cells treated with $50 \mu \mathrm{M}$ CLA; d cells treated with $75 \mu \mathrm{M}$ CLA; e cells treated with $100 \mu \mathrm{M}$
CLA; f Cells treated with $150 \mu \mathrm{M}$ CLA; g Cells treated with $200 \mu \mathrm{M}$ CLA. Fluorescent signal was detected by fluorescence microscope magnification $=\times 40$ 
Acknowledgements This research was supported by grant No. 50205-01124182-10482 from the Poznań University of Medical Sciences.

\section{Compliance with ethical standards}

Conflict of interest The authors declare that they have no conflicts of interest concerning this article.

Open Access This article is licensed under a Creative Commons Attribution 4.0 International License, which permits use, sharing, adaptation, distribution and reproduction in any medium or format, as long as you give appropriate credit to the original author(s) and the source, provide a link to the Creative Commons licence, and indicate if changes were made. The images or other third party material in this article are included in the article's Creative Commons licence, unless indicated otherwise in a credit line to the material. If material is not included in the article's Creative Commons licence and your intended use is not permitted by statutory regulation or exceeds the permitted use, you will need to obtain permission directly from the copyright holder. To view a copy of this licence, visit http://creativecommons.org/licenses/by/4.0/.

\section{References}

1. Bray F, Ferlay J, Soerjomataram I, Siegel RL, Torre LA, Jemal A (2018) Global cancer statistics 2018: GLOBOCAN estimates of incidence and mortality worldwide for 36 cancers in 185 countries. CA Cancer J Clin 68(6):394-424

2. Schwartz AG, Prysak GM, Bock CH, Cote ML (2007) The molecular epidemiology of lung cancer. Carcinogenesis 28(3):507-518

3. Molina JR, Yang P, Cassivi SD, Schild SE, Adjei AA (2008) Non-small cell lung cancer: epidemiology, risk factors, treatment, and survivorship. Mayo Clin Proc 83(5):584-594

4. Visioli F, Giordano E, Nicod NM, Dávalos A (2012) Molecular targets of omega 3 and conjugated linoleic Fatty acids'micromanaging' cellular response. Front Physiol 3:42

5. Kennedy A, Martinez K, Schmidt S, Mandrup S, LaPoint K, McIntosh M ( 2010) Antiobesity mechanisms of action of conjugated linoleic acid. J Nutr Biochem 21(3):171-179

6. Ha YL, Grimm NK, Pariza MW (1987) Anticarcinogens from fried ground beef: Heat-altered derivatives of linoleic acid. Carcinogenesis 8(12):1881-1887

7. Hubbard NE, Kelley NS, Erickson KL (2007) Conjugated Linoleic Acid Isomers and Cancer. J Nutr 137(12):2599-2607

8. Lu G et al (2015) c9, t11-conjugated linoleic acid induces HCC cell apoptosis and correlation with PPAR- $\gamma$ signaling pathway. Am J Transl Res 7(12):2752-2763

9. Huang G, Zhong X, Cao Y, Chen Y (2007) Antiproliferative effects of conjugated linoleic acid on human colon adenocarcinoma cell line Caco-2. Asia Pac J Clin Nutr 16(SUPPL.1):432-436.

10. El Roz A, Bard JM, Huvelin JM, Nazih H (2013) "The antiproliferative and pro-apoptotic effects of the trans9, trans 11 conjugated linoleic acid isomer on MCF-7 breast cancer cells are associated with LXR activation. Prostagland Leukot Essent Fat Acids 88(4):265-272

11. Sato K et al (2011) The change in conjugated linoleic acid concentration in blood of Japanese fed a conjugated linoleic acid diet. J Nutr Sci Vitaminol (Tokyo) 57(5):364-371

12. Spandidos DA (1985) Mechanism of carcinogenesis: the role of oncogenes, transcriptional enhancers and growth factors. Anticancer Res 5(5):485-498

13. Lehnen TE, da Silva MR, Camacho A, Marcadenti A, Lehnen AM (2015) A review on effects of conjugated linoleic fatty acid
(CLA) upon body composition and energetic metabolism. J Int Soc Sports Nutr 12:36

14. Villacorta L, Schopfer FJ, Zhang J, Freeman BA, Chen YE (2009) PPARgamma and its ligands: therapeutic implications in cardiovascular disease. Clin Sci (Lond) 116(3):205-218

15. Xia M, Duan M-L, Tong J-H, Xu J-G (2015) MiR-26b suppresses tumor cell proliferation, migration and invasion by directly targeting COX-2 in lung cancer. Eur Rev Med Pharmacol Sci 19(24):4728-4737

16. Feige JN, Gelman L, Michalik L, Desvergne B, Wahli W (2006) From molecular action to physiological outputs: Peroxisome proliferator-activated receptors are nuclear receptors at the crossroads of key cellular functions. Prog Lipid Res 45(2):120-159

17. Giaginis C, Politi E, Alexandrou P, Sfiniadakis J, Kouraklis G, Theocharis S (2012) Expression of peroxisome proliferator activated receptor-gamma (PPAR-gamma) in human nonsmall cell lung carcinoma: correlation with clinicopathological parameters, proliferation and apoptosis related molecules and patients' survival. Pathol Oncol Res 18(4):875-883

18. Elrod HA, Sun S-Y (2008) PPARgamma and apoptosis in cancer. PPAR Res 2008:704165

19. Tsubouchi Y et al (2000) Inhibition of human lung cancer cell growth by the peroxisome proliferator-activated receptorgamma agonists through induction of apoptosis. Biochem Biophys Res Commun 270(2):400-405

20. Bren-Mattison Y, Van Putten V, Chan D, Winn R, Geraci MW, Nemenoff RA (2005) Peroxisome proliferator-activated receptorgamma (PPAR(gamma)) inhibits tumorigenesis by reversing the undifferentiated phenotype of metastatic non-small-cell lung cancer cells (NSCLC). Oncogene 24(8):1412-1422

21. Keshamouni VG et al (2004) Peroxisome proliferator-activated receptor-gamma activation inhibits tumor progression in nonsmall-cell lung cancer. Oncogene 23(1):100-108

22. Fuenzalida $\mathrm{K}$ et al (2007) Peroxisome proliferator-activated receptor gamma up-regulates the Bcl-2 anti-apoptotic protein in neurons and induces mitochondrial stabilization and protection against oxidative stress and apoptosis. J Biol Chem 282(51):37006-37015

23. Ren $Y$ et al (2009) PPAR gamma protects cardiomyocytes against oxidative stress and apoptosis via Bcl-2 upregulation. Vascul Pharmacol 51(2-3):169-174

24. Fong WH, Da Tsai H, Chen YC, Wu JS, Lin TN (2010) Antiapoptotic actions of ppar- $\gamma$ against ischemic stroke. Mol Neurobiol 41(2-3):180-186

25. Calabrese EJ, Baldwin LA (2001) U-shaped dose-responses in biology, toxicology, and public health. Annu Rev Public Health 22:15-33

26. Rueden CT et al (2017) Image J2: IMAGEJ for the next generation of scientific image data. BMC Bioinform 18(1):529

27. Lubin JH, Caporaso NE (2006) Cigarette smoking and lung cancer: modeling total exposure and intensity. Cancer Epidemiol Biomarkers Prev 15(3):517-523

28. Wakelee HA et al (2007) Lung cancer incidence in never smokers. J Clin Oncol 25(5):472-478

29. Wahle KWJ, Heys SD (2002) Cell signal mechanisms, conjugated linoleic acids (CLAs ) and anti-tumorigenesis. Prostagland Leukot Essent Fat Acids 67:183-186

30. Cesano A, Visonneau S, Scimeca JA, Kritchevsky D, Santoli D (1998) Opposite effects of linoleic acid and conjugated linoleic acid on human prostatic cancer in SCID mice. Anticancer Res 18(3A):1429-1434

31. Ha YL, Storkson J, Pariza MW (1990) Inhibition of benzo(a)pyrene-induced mouse forestomach neoplasia by conjugated dienoic derivatives of linoleic acid. Cancer Res 50(4):1097-1101

32. Janani C, Ranjitha Kumari BD (2015) PPAR gamma gene-a review. Diabetes Metab Syndr Clin Res Rev 9(1):46-50 
33. Lee JE, Ge K (2014) Transcriptional and epigenetic regulation of PPAR $\gamma$ expression during adipogenesis. Cell Biosci 4(1):1-11

34. Ramiah SK, Meng GY, Ebrahimi M (2015) Upregulation of peroxisome proliferator-activated receptors and liver fatty acid binding protein in hepatic cells of broiler chicken supplemented with conjugated linoleic acids. Ital J Anim Sci 14(3):416-422

35. Gaetano C, Colussi C, Capogrossi MC (2007) PEDF, PPARgamma, p53: deadly circuits arise when worlds collide. Cardiovasc Res 76(2):195-196

36. Bonofiglio D et al (2006) Peroxisome proliferator-activated receptor-gamma activates $\mathrm{p} 53$ gene promoter binding to the nuclear factor-kappaB sequence in human MCF7 breast cancer cells. Mol Endocrinol 20(12):3083-3092

37. Amaral JD, Xavier JM, Steer CJ, Rodrigues CM (2010) The role of p53 in apoptosis. Discov Med 9(45):145-152

38. Majumder B et al (2002) Conjugated linoleic acids (CLAs) regulate the expression of key apoptotic genes in human breast cancer cells. FASEB J 16(11):1447-1449

39. Okura T, Nakamura M, Takata Y, Watanabe S, Kitami Y, Hiwada K (2000) Troglitazone induces apoptosis via the p53 and Gadd45 pathway in vascular smooth muscle cells. Eur J Pharmacol 407(3):227-235

40. Lynn Wang Y, Frauwirth KA, Rangwala SM, Lazar MA, Thompson CB (2002) Thiazolidinedione activation of peroxisome proliferator-activated receptor $\gamma$ can enhance mitochondrial potential and promote cell survival. J Biol Chem 277(35):31781-31788

41. Wu J-S, Lin T-N, Wu KK (2009) Rosiglitazone and PPAR-gamma overexpression protect mitochondrial membrane potential and prevent apoptosis by upregulating anti-apoptotic $\mathrm{Bcl}-2$ family proteins. J Cell Physiol 220(1):58-71

42. Lin $\mathrm{TN}$ et al (2006) 15d-prostaglandin $\mathrm{J} 2$ protects brain from ischemia-reperfusion injury. Arterioscler Thromb Vasc Biol 26(3):481-487

43. Ma LT et al (2010) Roles of peroxisome proliferator-activated receptor- $\alpha$ and $-\gamma$ in the development of non-small cell lung cancer. Am J Respir Cell Mol Biol 43(6):674-683
44. Li M-Y, Hsin MKY, Yip J, Mok TSK, Underwood MJ, Chen GG (2010) PPAR $\gamma$ activation extinguishes smoking carcinogen by inhibiting nnk-mediated proliferation. Am J Respir Cell Mol Biol 42(1):113-122

45. Lim DY, Tyner AL, Park JB, Lee JY, Choi YH, Park JHY (2005) Inhibition of colon cancer cell proliferation by the dietary compound conjugated linoleic acid is mediated by the CDK inhibitor p21 CIP1/WAF1. J Cell Physiol 205(1):107-113

46. Han S, Sidell N, Fisher PB, Roman J (2004) Up-regulation of p21 gene expression by peroxisome proliferator-activated receptor $\gamma$ in human lung carcinoma cells. Clin Cancer Res 10(6):1911-1919

47. Michalik L, Desvergne B, Wahli W (2004) Peroxisome-proliferator-activated receptors and cancers: complex stories. Nat Rev Cancer 4(1):61-70

48. Roman J (2008) Peroxisome proliferator-activated receptor $\gamma$ and lung cancer biology. J Investig Med 56(2):528-533

49. Sugawara A et al (2002) Transcription suppression of thromboxane receptor gene by peroxisome proliferator-activated receptor- $\gamma$ via an interaction with $\mathrm{Sp} 1$ in vascular smooth muscle cells. J Biol Chem 277(12):9676-9683

50. Takata Y, Kitami Y, Yang Z-H, Nakamura M, Okura T, Hiwada $\mathrm{K}$ (2002) Vascular inflammation is negatively autoregulated by interaction between CCAAT/enhancer-binding protein-delta and peroxisome proliferator-activated receptor-gamma. Circ Res 91(5):427-433

51. Miller WA, Wuertz BR, Ondrey FG (2018) PPAR $\gamma$-mediated p 21 induction in aerodigestive preneoplastic cell lines. Ann Otol Rhinol Laryngol 127(10):677-686

Publisher's Note Springer Nature remains neutral with regard to jurisdictional claims in published maps and institutional affiliations. 